\title{
ESR and ESR/U-series chronology of the Middle Pleistocene site of Tourville-la-Rivière (Normandy, France) - a
} multi-laboratory approach

Jean-Jacques BAHAIN ${ }^{1}$, Mathieu DUVAL ${ }^{2,3}$, Pierre VOINCHET ${ }^{1}$, Hélène TISSOUX ${ }^{1,4}$, Christophe FALGUERES ${ }^{1}$, Rainer GRÜN ${ }^{2}$, Davinia MORENO ${ }^{3}$, Qingfeng SHAO ${ }^{5}$, Olivier TOMBRET ${ }^{1}$, Guillaume JAMET ${ }^{6}$, Jean-Philippe FAIVRE $^{7}$ \& Dominique CLIQUET ${ }^{8}$

${ }^{1}$ UMR 7194 HNHP, Muséum National d'Histoire Naturelle, Département Homme et environnement, 1 rue René Panhard, 75013 PARIS. bahain@mnhn.fr, pvoinch@mnhn.fr, falguere@mnhn.fr, olivier.tombret@mnhn.fr

${ }^{2}$ Australian Research Centre for Human Evolution (ARCHE), Environmental futures Research Institute, Griffith University, NATHAN QLD 4111, Australia. m.duval@griffith.edu.au, rainer.grun@griffith.edu.au

${ }^{3}$ Geochronology, Centro Nacional de Investigación sobre la Evolución Humana (CNEIEHE), Paseo Sierra de Atapuerca, 3, 09002 Burgos, Spain.davinia.moreno@cenieh.es

${ }^{4}$ BRGM, DGR/GAT, 3 Avenue Claude Guillemin, BP 36009, 45060, Orléans, France and UMR7194 HNHP. h.tissoux@brgm.fr

${ }^{4}$ Geochronology, Centro Nacional de Investigación sobre la Evolución Humana, Paseo de Atapuerca, 3, 09002 Burgos, Spain davinia.moreno@cenieh.es

${ }^{5}$ Nanjing Normal University, College of Geography Science, Nanjing, China. qingfengshao@njnu.edu.cn

${ }^{6}$ GéoArchÉon SARL, 30, rue de la Victoire, F-55210 Viéville-sous-les-Côtes, France \& Laboratoire de Géographie Physique Environnements quaternaires et actuels (UMR 8591, CNRS-Universités Paris I \& Paris XII), 1 place Aristide Briand, F-92195 Meudon cedex, France guillaume.jamet@geoarcheon.fr

7 Université de Bordeaux, PACEA, UMR 5199, F_33615, Pessac Cedex, France. jean-philippe.faivre@ubordeaux.fr

${ }^{8}$ Service Régional de l'Archéologie, Direction régionale des Affaires culturelles de Basse-Normandie, 13bis, rue de Saint-Ouen, 14052 Caen cedex 04 \& UMR CNRS 6566, Université de Rennes 1, France: dominique.cliquet@culture.gouv.fr

Abstract - Tourville-la-Rivière (Normandy, France) is one of the rare Middle Pleistocene palaeoanthropological localities of Northern France. Electron Spin Resonance (ESR) and combined ESR/U-series dating methods were independently applied by different teams on sediments and teeth from this site. The present work provides an overview of this multi-laboratory dating work by integrating a description and discussion of the methodologies employed and results obtained.

Results confirm that the ESR/U-series analyses of the teeth are greatly dependent on the U-uptake histories of the dental tissues. Although all teeth come from the same archeological level, the samples analysed by each team display two different patterns for the U-series data. This is most likely related to the different sampling areas selected by each team and may be interpreted as the result of local variations in the geochemical conditions of the surrounding environment. Concerning the ESR dating of optically bleached quartz grains, the use of the multiple centre approach seems crucial when dating such fluvial and fluvio-lacustrine sediments. Our results also confirm the great potential of the Ti-H centre to date late Middle Pleistocene deposits.

Despite some (expected) discrepancies related to the independent use of parameters and approaches by the different teams involved in this multi-laboratory study, the whole ESR and ESR/U-series data set collected from Tourville-la-Rivière locality consistently correlates stratigraphic levels D1 to I and associated human occupation to MIS7.

Keywords - Electron Spin Resonance dating; combined ESR/U-series dating; Tourville-la-Rivière; Middle Pleistocene; teeth; optically bleached quart grains.

1. Introduction 
Since the late 1980s, Electron Spin Resonance (ESR) of optically bleached quartz grains and combined ESR/Useries of fossil teeth are amongst the most employed dating applications to constrain the chronology of Middle Pleistocene archaeo-palaeontological sites. Previous cross-comparison studies showed good agreement with results derived from other numerical dating methods such as Luminescence, U-series and ${ }^{40} \mathrm{Ar}-{ }^{39} \mathrm{Ar}$ (e.g. Duval et al., 2017; Méndez-Quintas et al., 2018; Pereira et al., 2018). Unfortunately, given the very limited number of laboratories and researchers specialized in the ESR dating applications mentioned above, inter-laboratory comparison studies remain very rare. Additionally, the material analyzed is typically quite small and heterogeneous, which does not facilitate the implementation of such large-scale comparative programs.

Sometimes, a given site or archaeological level has been dated with ESR or ESR/U-series methods by different teams in separate works, such as for example the sites of La Micoque (Dordogne, France) (Schwarcz and Grün, 1988; Falguères et al., 1997) or Atapuerca Gran Dolina TD6 (Spain) (Falguères et al., 1999; Duval et al., 2018) or, more rarely, within the framework of a single study (e.g. Dirks et al., 2017). However, except for critical evaluations of previously published data, these studies have in most cases not led to any proper scientific discussions about the experimental conditions employed and their impact on the final age estimates.

Tourville-la-Rivière is one of the rare Middle Pleistocene palaeoanthropological localities of Northern France. It has recently been submitted to a series of independent dating studies by different ESR dating laboratories (CENIEH-RSES, MNHN and BRGM) involving combined ESR/U-series dating of fossil teeth (CENIEH-RSES in Faivre et al., 2014; MNHN in Bahain et al., 2015) and ESR dating of optically bleached quartz grains (MNHN and BRGM, unpublished data). The present paper aims to compile all the chronological data collected for this site in order to enable a proper comparison of the different methodologies employed (from sampling to age determination) and evaluate their impact on the age results. When necessary, new age calculations were performed in accordance to recent methodological developments. These data will contribute to refine the chronology of the different archaeological and geological levels for this key palaeoanthropological locality.

\section{Tourville-La-Rivière site}

Located on a low fossil fluvial terrace of the Seine System, close to Rouen city in Normandy (Figure 1), Tourvillela-Rivière site (Seine-Maritime, France) has been known since the late 1960s (see Lautridou, 1985 and Jamet, 2015 and references therein). Several areas within the site have been successively excavated during the following fifty years, delivering an abundant late Middle Pleistocene mammal fauna (Auguste, 2009; Bemilli 2010, 2014), a rich archaeological Middle Paleolithic lithic assemblage (Cliquet et al., 2010; Faivre et al., 2014) and three human arm bones attributed to an individual of the Neanderthal lineage (Faivre et al., 2014).

Figure 1 - Location of the Tourville-la-Rivière site, Northern France, in the Seine valley terrace system (after Jamet, 2015)

Tourville-la-Rivière offers one of the longest Middle Pleistocene continental stratigraphic sequences $(>30 \mathrm{~m}$ thick) in Western Europe (Lautridou, 1985) (Figure 2). At least two climatic cycles are recorded on a fluvial terrace level corresponding to the T2 terrace of the Seine system (Figure 1). The lower part of the sequence (units A-D) consists of periglacial coarse sands and gravels units with intercalations of fine-grained interglacial fluvial or estuarine sediments. The upper part (units $E$ to J) corresponds to successions of fine-grained sediments, gravels and paleosols, covered by periglacial slope deposits (units K and L) (Lautridou, 1985 ; Jamet, 2015 ; Chauhan et al., 2017). Chronological data available before 2014 (ESR on mollusk shells, Stremme, 1985; Amino acid racemization (AAR) also on mollusk shells, Ochhietti et al., 1987; thermoluminescence (TL) and Infra-red stimulated luminescence (IRSL) on sediments, Balescu et al., 1997; see data in Table 2) correlated the fluvial and estuarine deposits to the Saalian stage and place the deposition of units B and D1 during MIS 9 and 7 , respectively.

The locality has recently been the subject of two successive archaeological excavation campaigns in 2008 (Cliquet et al., 2010) and 2010 (Faivre et al., 2014) and a new stratigraphic study was performed within the framework of Guillaume Jamet's PhD thesis (Jamet, 2015). The latter enabled to propose that the position of the end of the MIS7 is recorded higher up in the sequence, i.e. between units $E$ and F instead of between D1 and D2 as previously proposed by Lautridou (1985) (Figure 2). 
Figure $\mathbf{2}$ - Overview of the sedimentary sequence at Tourville-la-Rivière, including stratigraphic subdivision, identified biomarkers, numerical dating results available before the recent ESR/U-series and ESR studies, and palaeoenvironmental interpretation (after Jamet, 2015)

\section{Electron Spin Resonance (ESR) dating: basic principles}

\section{a. Combined ESR/U-series dating of fossil teeth}

The combined use of electron spin resonance (ESR) and U-series dating methods (ESR/U-series) to date Pleistocene mammal remains has been first proposed at the end of 1980s (Grün et al., 1988). The age calculation for a tooth requires the determination of two parameters: an estimate of the total dose of radiation received during its archaeological history, usually named equivalent dose $\left(D_{e}\right)$, and the dose rate $\left(d_{a}\right)$, i.e. an estimate of the dose annually absorbed by the sample. The $D_{e}$ value is classically determined using a multiple aliquot additive dose (MAAD) method. The dose rate is assessed from the radioelement content of the sample itself and of the surrounding sediment, in addition to a component from the cosmic rays (sees Duval, 2015 for further detail).

The main complication in combined ESR/U-series dating of fossil teeth is related to the uranium incorporation into dental tissues during the fossilization process. This phenomenon depends on the considered tissue, of the geological nature of the site and of its age. It requires the use of mathematical models allowing the description of the U-content evolution with time in a given tissue. The most popular one, uranium-series (US) model, has been proposed by Grün et al. (1988), who introduced a parameter (p) to describe the U-uptake kinetics for each dental tissue. This kinetics is mathematically assessed from the ESR and present-day U-series data measured in each dental tissue. Consequently, only one combined US-ESR age fits the available dataset (see Shao et al., 2015 for the mathematical basis of the US model).

The US model can only be applied if the ESR age calculated assuming an early U-uptake (EU) for all the tissues of a tooth is greater than the corresponding EU-U-series ages. In other words, the occurrence of U-leaching would preclude the use of the US model, which may frequently occur in Pleistocene open air sites. More recently, Shao et al. (2012) proposed the accelerated uptake (AU) model in order to enable combined Useries/ESR age calculations in presence of uranium leaching.

Another alternative to the US model is the closed system uranium-series (CSUS or CSUS-ESR) model that assumes that all uranium migrated into the dental tissue at the time given by the apparent closed system $U$ series age (Grün 2000). On a given data set, the CSUS model typically provides a maximum possible age estimate. By using both CSUS and US models for a given sample, the resulting age range typically encompass all possible U-uptake histories (e.g. Duval et al., 2018), as long as there are no U-leaching episodes.

\section{b. ESR dating of optically bleached quartz grains}

Unlike for fossil teeth, ESR dating of quartz grains is based on the evaluation of light-sensitive signals. The exposure of quartz grains to natural sunlight (an especially to UV-rays; Tissoux et al., 2007) leads to the significant decrease of the intensity associated to the ESR signal some paramagnetic centres. This phenomenon, called optical bleaching, corresponds to a drain of trapped electrons in relation to the energy received during the light exposure (Toyoda et al., 2000). Hence, the event tentatively dated here is not crystal formation, as for the speleothems, or a biological event, as for palaeontological remains, but the last exposure of the quartz grains to the sunlight before their burial into the sediment (Yokoyama et al. 1985).

However, the different ESR centres measured in quartz do not all show the same bleaching features. If the ESR intensity of the titanium ( $\mathrm{Ti}$ ) centres (mainly $\mathrm{Ti}-\mathrm{H}$ and $\mathrm{Ti}-\mathrm{Li}$ ) can be fully reset, the aluminium (Al) signal cannot be zeroed instead. Its ESR intensity decreases until a plateau value corresponding to the presence in the quartz of traps that cannot be emptied by light exposure (Toyoda et al., 2000; Tissoux et al., 2012). This residual value is sample dependent: it is typically determined by exposing an aliquot of the natural sample to a UV solar simulator(e.g. Voinchet et al., 2003). The ESR intensity corresponding to the non-bleachable part of the ESR Al signals is then subtracted to the ESR signal intensity of the studied sample before any $D_{e}$ determination (socalled total bleach method, Forman, 2000). The resulting $D_{e}$ value corresponds to the total dose of radiation received by the sample during burial (Voinchet et al. 2004). 
In order to evaluate the bleaching level achieved by the ESR signals during sediment transport, an approach based on the measurements of $\mathrm{Al}$ and Ti signals (multiple centre approach, $\mathrm{MC}$ ) was first proposed by Toyoda et al. (2000). This MC approach aims to take advantage of the different bleaching kinetics typically observed for the $\mathrm{Al}, \mathrm{Ti}-\mathrm{Li}$ and $\mathrm{Ti}-\mathrm{H}$ centres. The $\mathrm{Ti}-\mathrm{H}$ signal is known to be fully reset at a much faster rate than the Ti-Li signal, while the Al signal shows a much slower bleaching kinetics in comparison (Toyoda et al., 2000; Duval et al., 2017). Incomplete bleaching would therefore lead to different burial dose estimates for these three ESR signals, with the Ti-H signal typically providing the smallest dose and the Al signal the biggest one. In this case, the first one would most likely be the closest estimate of the true burial dose absorbed by the sample, whereas the second one would provide a maximum possible estimate (see Duval et al., 2017). However, the systematic application of the MC approach is sometimes complicated by the weak ESR signal measured for the Ti-H centre (see Rixhon et al., 2017), which makes it complicated to obtain meaningful results.

A few recent applications studies may provide a fair idea of the time range applicability achieved by the MC approach. Ti-H signal has proven to produce age estimates consistent with independent age control from about $300 \mathrm{ka}$ to $40 \mathrm{ka}$ (e.g., Duval et al., 2017; Kreutzer et al., 2018), while Ti-Li and Al centres may provide accurate age results between about $200 \mathrm{ka}$ and $2 \mathrm{Ma}$ (Beerten and Stesman, 2006; Mendez-Quintas et al., 2018; Sahnouni et al. 2018; Voinchet et al., this issue). For a time period younger than about $40 \mathrm{ka}$, none of the $\mathrm{Al}$ and Ti centres seem to yield accurate age results (e.g., Mendez-Quintas et al., 2018), which indicate the difficulty to detect low dose estimates ( $<100 \mathrm{~Gy}$ ) with these signals. Finally, one may not exclude that the lower dating limit of the ESR method may well be beyond $2 \mathrm{Ma}$, as suggested in first instance by the few existing thermal stability studies (see an overview in Toyoda, 2015). However, it is still unclear whether these laboratory estimates are accurate given the uncertainty involved in the evaluation process and the impossibility to reproduce natural condition during annealing experiments.

\section{Material and methods}

\subsection{Combined ESR/U-series dating of fossil teeth}

Eight fossil teeth from the 2010 excavation (Figure 3) were analyzed by the CENIEH-RSES (Centro Nacional de Investigación sobre la Evolución Humana, Spain - Research School of Earth Sciences, Australian National University, Australia) team (see details in Faivre et al., 2014): five of them were found in the lower part of Layer $\mathrm{D} 2(\mathrm{~T} 1, \mathrm{~T} 2, \mathrm{~T} 4, \mathrm{~T} 5$ and $\mathrm{T} 8)$ and three in the upper part (T3, T6 and T7). Four sediment samples were collected from Layer D2, with three in direct contact with $\mathrm{T} 4, \mathrm{~T} 5$ and $\mathrm{T} 7$. They were used to derive the external beta and gamma dose rate values. Since the dating analyses started at the end of 2011, i.e. more than one year after the end of the excavation (September 2010), the excavation site could no longer be accessed to carry out in situ gamma dose rate measurements.

Figure 3 - Sampling location of the analyzed teeth and sediments from the Tourville-la-Rivière site

Six horse teeth from the D2 level excavated in 2008 and associated sediments (Figure 3) have been analyzed by the MNHN (Muséum National d'Histoire Naturelle, France) team following the experimental protocol described in Bahain et al. (2012). In situ gamma dose rate evaluation was also performed in 2011 on an outcrop connecting the two main excavation areas. Four measurements were performed within D2 layer in order to evaluate lateral variations of radioactivity.

The analytical protocols followed by the two teams are summarized in Table 1. They are quite similar for the sample preparation and $D_{e}$ determination, but differ for the $\mathrm{U}$-series analyses and some of the ESR parameters used in the age calculation. The main differences may be summarized as follows: (i) external dose rate was determined from laboratory analyses of sediment only for CENIEH-RSES tooth samples, while gamma dose rate of the MNHN samples was derived from in situ measurements; (ii) Potential Rn losses from the dental tissues was evaluated for the MNHN samples, while equilibrium was assumed for the CENIEH-RSES teeth; (iii) the cosmic dose rate was estimated from the present-day depth by CENIEH-RSES team (i.e. $21 \mathrm{~m}$, leading to a cosmic dose of $26.8 \mu \mathrm{Gy} / \mathrm{a}$ ), while MNHN used a geological model based on the sediment deposition

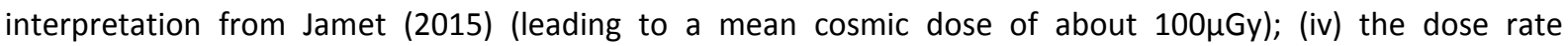


conversion factors from Adamiec and Aitken (1998) and Guérin et al. (2011) were used by MNHN and CENIEHRSES teams, respectively; (v) DATA (CENIEH-RSES)(Grün, 2009) and USESR (MNHN)(Shao et al., 2015) combined ESR/U-series age calculation programs were employed.

Table 1 - Comparison of the analytical procedures used by the CENIEH-RSES and MNHN teams for the combined U-series/ESR dating of fossil teeth.

\subsection{ESR dating of quartz grains}

Six sediment samples were collected in 2011 at Tourville-la-Rivière, two from the D1 level (Tourville 5 \& 6) and another four from the D2 level (Tourville 1 to 4). These last four samples actually correspond to the in situ gamma measurement points used for the MNHN teeth (Figure 3). In situ gamma measurements were systematically performed at each sampling point using an Inspector1000 Canberra gamma spectrometer. Gamma dose rate were obtained using the threshold approach. By this approach, the count-rate of the spectrometer, proportional to the gamma dose-rate, is directly determined independently of the radioelements sources (U, Th, K) (see details in Mercier \& Falguères, 2007).

Four sediment samples were collected by the BRGM (Bureau de Recherche Géologique et Minière, France) team in 2013 (TVL1301 to 04) from one new section cleaned and studied by Guillaume Jamet during his PhD (Figure 4), located approximately $150 \mathrm{~m}$ ESE from the MNHN sampling section (Figure 3). One sample was taken from the D1 level (TVL1304) and the other three from I level. Here again, in situ gamma spectrometry measurements were systematically performed using an Ortec Digidart LF gamma spectrometer and gamma dose rates derived from the Threshold approach.

Figure 4 - Sampling location of the 2013 sediments from Tourville-la Rivière analyzed by the BRGM team.

The two teams employed the same preparation and measurement procedure. Quartz grains were extracted using physical and chemical preparation techniques described in Voinchet et al. (2004). Aliquots were irradiated using a panoramic ${ }^{60} \mathrm{Co}$ source (Dolo et al., 1996) with $1.25 \mathrm{MeV}$ gamma rays and a dose rate of $200 \mathrm{~Gy} / \mathrm{h}$. Applied irradiation dose values range from 260 to $12,000 \mathrm{~Gy}$.

ESR measurements were performed on 100-200 $\mu \mathrm{m}$ quartz grains. The MNHN team measured the Al signal only in all the quartz samples, whereas the BRGM applied the MC approach on two of the four samples analysed (TVL1302 and TVL1304). The residual (non-bleachable) part of the Al signal was determined after exposing the samples to UV light in a Dr Hönhle SOL2 solar simulator for about $1600 \mathrm{hrs}$. The light intensity received by each artificially bleached samples was comprised between 3.2 et 3.4.10 $0^{5}$ Lux. ESR measurements were performed at $107 \mathrm{~K}$ with an EMX Bruker ESR X-band spectrometer using the experimental conditions outlined by Voinchet et al., (2004). Al-signal intensities were measured from the top of the first peak of the hyperfine structure of the quartz ESR spectra at $g=2.018$ and the bottom of the $16^{\text {th }}$ peak at $g=2.002$ (Toyoda \& Falguères, 2003).

The Ti-Li centre intensity was measured from the bottom of the peak at $\mathrm{g}=1.913$ to the baseline (so called option D in Duval and Guilarte, 2015) and the Ti-H centre signal intensity from the bottom of the doublet at $\mathrm{g}=$ 1.915 to the baseline (so called option C in Duval and Guilarte, 2015). For each centre, the average and the standard deviation of three repeated measurements were calculated and used for $D_{e}$ determination.

Dose response curves (DRCs) were obtained by fitting an exponential+linear equation $(E+L)$ function through the experimental data points (Duval, 2012; Cordier et al., 2012). Fitting was performed using Microcal OriginPro 8, with data weighted by the inverse of the square intensities.

The analytical protocols used by the two teams are compared in Table 2. Sample preparation, dose rate evaluation and age calculation are strictly similar for the two procedures. Both teams used measured water content for dose rate evaluation. The main differences concern: (i) the use of the MC approach by BRGM team; (ii) the maximal dose of irradiation $\left(D_{\max }\right)$ employed by each team $(9,870$ Gy for MNHN vs 11,700 Gy for BRGM)'; (iii) the water content considered for the age calculation(5-8\% for MNHN and $10-12 \%$ for BRGM, which is most likely the result of different weather conditions before and during sampling).

Table 2 - Comparison of the analytical protocols used by the MNHN and BRGM teams for the ESR dating of the Tourville sediments. 


\subsection{Combined ESR/U-series age estimates on teeth}

\subsubsection{CENIEH-RSES}

A summary of the analytical data and results obtained by the CENIEH-RSES team is given in in Table 3. Three of the teeth from lower D2 (T4, T5 and T8) show the highest apparent U-series ages, which precluded any combined US-ESR age calculation for these samples. In contrast, the tooth samples from the upper D2 show a somewhat distinct pattern. The cement tissues of samples T6 and T7 have apparent U-series ages that are significantly older than the other tissues, which again precluded a straightforward US-ESR calculation. In summary, combined US-ESR age calculation was possible for only 3 of the 8 teeth (see also Faivre et al., 2014). All resulting age estimates are within the one-sigma error range. They are between 174 ka and 208 ka for teeth T1, T2 (both from lower D2) and T3 from the upper part of D2. The limited age scatter (relative standard deviation of about $9 \%$ ) may be partially explained by some lateral variations in the sediment radioactivity: the external dose rate derived from the different sediment samples collected within D2 varies by about $4 \%$.

Interestingly, the CSUS-ESR estimates are somewhat older but nevertheless consistent with the standard USESR ages, indicating thus that the U-uptake modelling has a very limited impact on the final age results. They vary between $188 \pm 21$ and $236 \pm 29$ ka (Table 3). Based on the weighted mean US-ESR and CSUS-ESR ages, the best age range estimate for the teeth derives from the error range given by both models, i.e. 183 to 226 ka, which represents the middle part of MIS 7 to the beginning of MIS 6.

Table 3: U-series and ESR data obtained by the CENIEH-RSES team (modified from Faivre et al., 2014)

\subsubsection{MNHN}

Although the combined US-ESR age results obtained by the MNHN team have been published earlier in Bahain et al. (2015), the data obtained were not fully given and will therefore be detailed in the present paper (Table 4).

Contrary to the earlier dating study by Faivre et al (2014), the use of the US model for the age calculation was possible for all the teeth, indicating more homogeneous U-uptake behaviours and no occurrence of uranium leaching. The teeth analyzed by the MNHN team display relatively similar paleodosimetric parameters: the $D_{e}$ dispersion is low (from $191 \pm 6$ to $220 \pm 2$ Gy, around 6\%; Table 4); the p parameters describe early uptake (p values between -0.93 and -0.69 , Table 4 ) for all the tissues; the external environmental dose rate measured in situ within the D2 layer shows a very limited lateral variability (5\%), demonstrating thus the homogeneity of the sedimentary environment (a mean value of $417 \pm 21 \mu \mathrm{Gy} / \mathrm{a}$ was used for the age calculation). Hence, the age results obtained for the six teeth show relatively little scatter, i.e. between $203 \pm 13 \mathrm{ka}$ and $249 \pm 15 \mathrm{ka}$. A mean age of $224 \pm 11$ ka could be calculated using IsoPlot 3.0 software (Ludwig, 2003) for the D2 level, unequivocally placing the deposition of this layer during MIS7, and probably during the first part of this stage. A consistent CSUS-ESR weighted mean age of $241 \pm 11$ ka was obtained, indicating that the U-uptake modelling has a very limited impact on the final age result, similarly to the other dating results obtained by Faivre et al (2014).

Table 4 - U-series and ESR data obtained by the MNHN team. Analytical uncertainties are given at the onesigma level. * The depth was estimated from the chronostratigraphic interpretation of Jamet (2015).

\subsection{ESR on optically bleached quartz grains}

\subsubsection{MNHN}

The radioelement contents, ESR ages and associated dose rate contributions determined for the Tourville-laRivière D1 and D2 sediments at MNHN are displayed in Table 5. 
Table 5- Radioelement contents, equivalent doses, bleaching rate, dose rate contributions and ESR ages obtained for the sediments of the Tourville-la-Rivière D1 and D2 levels dated by the MNHN team. The bleaching coefficient represents the relative difference between the ESR intensities of the natural and bleached aliquots. Analytical uncertainties are given at the one-sigma level.

Even if bleaching coefficients vary within narrow range for the whole set of samples from D2 (from 42 to $51 \%$; Table 5), the equivalent dose values differ by a factor of 2.6, while the dose rate are all around 1100-1200 $\mu \mathrm{Gy} / \mathrm{a}$. Consequently, the resulting ESR ages significantly vary, from $349 \pm 30$ to $906 \pm 70 \mathrm{ka}$. In comparison, the two ESR ages obtained for the D1 level show a limited scatter, with values ranging from $334 \pm 90$ to $390 \pm$ $60 \mathrm{ka}$. This difference between the two levels is probably related with the deposition environment: D1 level is made of coarser sediments than D2, indicating a deposition along the river bank rather than in the floodplain in high water periods. This may explaine why bleaching appears to be more homogeneous among D1 samples compared with D2. Following the principles of the MC approach, all these ESR age results obtained from the measurement of the Al centre only should in first instance be interpreted as maximum possible burial age estimates for D1 and D2 levels.

\subsubsection{BRGM}

The results obtained for the samples processed by the BRGM team are displayed in Table 6. The MC approach was employed for two samples (TVL-1302 and TVL-1304) while only the Al-signal was measured for the two other samples.

Table 11 - Radioelement contents, equivalent doses, bleaching rate, dose rates contributions and ESR ages obtained for the sediments of the Tourville-la-Rivière D1 and I levels analyzed by the BRGM team. Analytical uncertainties are given at the one-sigma.

In the D1 level, bleaching coefficients of the Al centre determined by the BRGM team are close to those obtained by the MNHN one (42 vs. $46 \%$ ). Similarly, the total dose rate values are slightly lower but nevertheless consistent at a one-sigma level. In particular, the in situ gamma dose rate of TVL-1304 is the same as the dose measured by MNHN team in this level (samples Tourville 5 and 6; Table 5). Interestingly, both Al and Ti-Li ESR ages are in close agreement around 980-990 ka, and both significantly older than the results derived from MNHN samples of the same level (334 $\pm 90 \& 390 \pm 60 \mathrm{ka}$; Table 4). In contrast, Ti-H signal provides a significantly younger age of $243 \pm 14 \mathrm{ka}$. Following the principles of the MC approach, these age differences between $\mathrm{Al}, \mathrm{Ti}-\mathrm{Li}$ and Ti-H centres may simply reflect an incomplete bleaching of the former two signals during sediment transport. Consequently, the $\mathrm{Ti}-\mathrm{H}$ age result is interpreted as being the closest estimate to the true burial age of the sample. This age is actually highly consistent with those derived from the teeth of level D2 above (Tables $3 \& 4$ ).

In contrast, the three samples from level I display very close total dose rate values (around 500-550 $\mu \mathrm{Gy} / \mathrm{a}$ ) and highly scattered $D_{e}$ estimates from the Al centre ranging from $187 \pm 73$ Gy to $737 \pm 178 \mathrm{~Gy}$. As a consequence, The Al ESR ages vary from $535 \pm 22$ to $1354 \pm 283 \mathrm{ka}$. The Ti-Li signal measured in sample TVL-1302 displays a significantly younger age estimate (by about $44 \%$ ) compared with that of the Al signal. Similarly, the Ti-H signal produced an even younger result (-27\% compared with Ti-Li). This pattern is comparable to that observed for TVL-1304: it suggests an incomplete reset of both the Al and Ti-Li signals prior to sediment burial. In accordance with the MC approach, the Ti-H signal most likely provides the closest estimate ( $236 \pm 49 \mathrm{ka})$ to the true burial age for this sample.

Samples TVL-1304 (level D1) and TVL-1302 (level I) are located at the bottom and top of the local sequence, respectively, and bracket the human occupation from level D2. They provide very close Ti-H ESR age results $(243 \pm 14$ vs. $236 \pm 49 \mathrm{ka})$. As consequence, no apparent stratigraphic pattern is observed. This may be interpreted in first instance as an evidence of relatively rapid sedimentation from level D1 to D2. These results allow the correlation of the D1 to I levels to MIS7.

\section{Discussion}


The two sets of ESR and U-series data obtained on fossil teeth by the two independent teams involved in the Tourville study are overall in good agreement (Figure 5). However, the CENIEH-RSES samples displays more scattered $D_{e}$ (Figure $5 A$ ) and $U$-series (Figure $5 B$ ) data than $M N H N$, while uranium concentration values in dental tissues overall vary within the same range (Figure $5 C$ ).

Figure 5 - ESR/U-series data obtained on the Tourville-la Rivière teeth analyzed by the CENIEH-RSES and MNHN teams. A) Equivalent dose values; B) U-series data; C) U-content of the dental tissues; D) ESR/U-series (US and CSUS) and corresponding age density probability plots.

We can observe in particular that a majority of the CENIEH-RSES teeth recovered during the 2010 excavation are close or beyond of the U-series applicability domain, preventing the use of US model for these teeth (Figure $5 B$ ). The overall smaller $D_{e}$ values obtained for most of the teeth (Figure $5 A$ ) also constitute an additional limiting factor, which explains why US-ESR ages could only be calculated for three teeth. In comparison, the MNHN teeth recovered during the 2008 excavation provide more homogeneous ESR and U-series data and seem to have experienced relatively simple (and relatively early) U-uptake histories, with $p$-values ranging between -1 and -0.7 . In contrast, CENIEH-RSES have apparently experienced more complex U-uptake, including U-leaching. This difference could be correlated to the origin of the teeth, with one excavation area (2008) that underwent more favorable geochemical conditions from an ESR dating perspective in comparison with the other (2010 area). This hypothesis is supported by the fact that two of the three CENIEH-RSES teeth that could be dated are spatially located the closest to the 2008 excavation area (Figure 3).

The MNHN tooth samples yield a weighted mean US-ESR and CSUS-ESR age of $224 \pm 11$ ka and $241 \pm 11$ ka, respectively. CENIEH-RSES results are both $\sim 14 \%$ lower with $194_{-11}^{+14} \mathrm{ka}$ and $211 \pm 15 \mathrm{ka}$ for the US and CSUS models, respectively. Nevertheless, both data sets overall at a two-sigma confidence level, supporting thus their consistency. Consequently, US-ESR and CS-US-ESR weighted mean ages of $218 \pm 16 \mathrm{ka}$ and $236 \pm 16 \mathrm{ka}$ may be calculated, respectively (Figure 5D). These results permit to unambiguously correlate the human occupation of the D2 level to MIS 7.

Although both independent data sets are consistent, we acknowledge that there may be a systematic component in the uncertainty due to differences in the analytical procedures, which might partly explain this overall $14 \%$ age underestimation of the CENIEH-RSES vS MNHN age results. This age underestimation may be the result of either $a D_{e}$ underestimation or a dose rate overestimation, or possibly a combination of both.

For example, the impact of the absence of in situ gamma dose rate evaluation for the CENIEH-RSES samples can hardly be evaluated. If the impact of the water contents used for age calculations is low (less than $2 \%$ ) for both dental tissues and sediment, it could be envisaged in first instance that a somewhat overestimated gamma dose rate has been derived from the laboratory analysis of unrepresentative (at a gamma-ray scale) sediment samples. However, the gamma+cosmic dose rate estimated for $2 / 3$ CENIEH-RSES samples are already significantly lower than those obtained for the MNHN samples, mainly in relation to the cosmic dose rate used for the age calculation (26.8 $\mu \mathrm{Gy} / \mathrm{a}$ for the CENIEH-RSES samples vs $100 \mu \mathrm{Gy} / \mathrm{a}$ for the MNHN ones). Consequently, an additional overestimation of this parameter may be considered as unlikely.

The impact of using different dose rate conversion factors (Adamiec and Aitken (1998) and Guérin et al. (2011) for MNHN and CENIEH-RSES, respectively) is typically estimated to be <1\% (e.g., Liritzis et al., 2013), and can therefore here considered to be negligible. Finally, any bias induced by the use of different combined ESR/Useries age calculation programs is also to be negligible $(<1 \%)$, as shown earlier in the comparison study by Shao et al. (2014).

Additionally, the $D_{e}$ values initially considered by Faivre et al (2014) and Bahain et al. (2015) have been recalculated based on the more recent work by Duval and Grün (2016) for the selection of the maximum applied dose $\left(D_{\max }\right)$ in order to avoid $D_{e}$ overestimation. Based on their recommendations, and given the magnitude of the $D_{e}$ values (between 100 and $250 \mathrm{~Gy}$ ), the $D_{\max } / D_{e}$ ratio should be somewhere of between 5 and 10, whereas it is ranging from 20 to 41 for the previously published data (see Table 7). Consequently, new fittings were performed with the same program (Origin), function (SSE), data weighing option $\left(1 / I^{2}\right)$ and the appropriate $D_{\text {max }} / D_{e}$ ratio. The resulting $D_{e}$ values remain all within error, although a slight mean decrease of about $3 \%$ of about $6 \%$ may be observed for the CENIEH-RSES and MNHN data sets, respectively. One may note 
that the errors on the revised $D_{e}$ values are overall higher than those obtained earlier, which is simply the result of a fitting performed with a more reduced number of experimental data points (6-8 instead of 10 previously). In summary, the use of a smaller $D_{\max }$ value has a very limited impact on the corrected $D_{e}$ value for most of the teeth, and is most likely not the main reason for the overall age difference of $\sim 14 \%$ between the two data sets.

In fact, most of this age difference probably comes from the consideration of radon loss from dental tissues by the MNHN team, while a radioactive equilibrium was assumed by the CENIEH-RSES team. The Rn loss measured on both dentine and enamel of the MNHN teeth is quite important for the most of the analyzed tissues $\left({ }^{222} \mathrm{Rn} /{ }^{230} \mathrm{Th}\right.$ ratio ranging from 0.247 to 0.523 , except for two tissues showing equilibrium, Table 4). If equilibrium was assumed for these tissues, this would lead to a decrease of the age estimates ranging from 20.7 to $-5.8 \%$ depending on the samples considered. Moreover, it would no longer be possible to use the US model for two samples (TVL 160 and TVL 923).

Lastly, if the MNHN ages are recalculated using the CENIEH-RSES parameters (conversion factors from Guérin et al.(2011) same water contents of dental tissues and sediments, Rn equilibrium, cosmic dose corresponding to a $21 \mathrm{~m}$-depth, gamma dose calculated from the sediment contents), the age estimates decrease for four samples (-12.0 to $-13.8 \%)$ and increase for two of them ( +1.2 to $+8.0 \%)$ leading to a reduced mean age difference of $-7.8 \%$ between the two sets of samples.

Table 7 - Comparison of the equivalent dose values obtained with or without use of the recommendations by Duval and Grün (2016).

Concerning ESR dating of quartz, all the Al and Ti-Li ESR ages look strongly overestimated (in perhaps a lesser extent for the Ti-Li) compared with the existing chronological framework, the combined ESR/U-series ages and $\mathrm{Ti}-\mathrm{H}$ ESR ages (Figure 6). In accordance with the principles of the MC approach, this overestimation is most likely due to incomplete bleaching (Duval et al., 2017). The geological nature of the D2 sediment (silty clayey deposits) could indicate a turbid water deposit in a decantation environment such as floodplain or muddy supratidal area. It could explain the age overestimate for Al and Ti-Li centres in this level (see also Voinchet et al., 2015). A similar hypothesis can be made for sandy levels D1 and I. The fluvio-estuarine origin of the sediments seems to constitute an unfavorable environment to completely reset the Al and Ti-Li signals.

In comparison, given its bleaching kinetics, $\mathrm{Ti}-\mathrm{H}$ centre is by definition most likely to have been fully reset during sediment transport. Ti-H ESR results ( $243 \pm 14 \mathrm{ka}$ and $236 \pm 49 \mathrm{ka}$ for units D1 and I respectively) in close agreement with the US-ESR ages obtained on fossil teeth (weighted mean age of $218 \pm 16 \mathrm{ka}$ ). All together, these data consistently date the deposition of the Tourville D1 to I units to the first part of MIS 7 rather than to the end of this interglacial stage as previously considered (Lautridou, 1985; Balescu et al., 1997). These results demonstrate the importance of using the MC approach in ESR dating of optically bleached quartz grains, which is the only way to evaluate potential incomplete bleaching of Al and Ti centres prior to burial.

Figure 6 - ESR ages obtained on the Tourville-la Rivière sediments analyzed by the MNHN and BRGM teams using different quartz ESR centres. The grey band corresponds to the MIS 7 time range.

\section{Conclusion}

Tourville-la-Rivière is one of the very few Pleistocene localities where successive and independent ESR and ESR/U-series dating studies have been performed by different teams. The ESR and U-series analyses of fossil teeth show two different populations of samples with different characteristics: the MNHN samples from the 2008 excavation are display homogeneous ESR and U-series data and seem to have experienced relatively simple U-uptake histories, while the scattered results obtained on CENIEH-RSES teeth (2010 excavation area) indicate a more complex evolution, including uranium leaching processes. Despite some differences in the analytical protocols independently used by each team, combined ESR/U-series age results consistently position the palaeontological remains and lithic series of D2 layer within MIS7. 
Concerning the ESR dating of optically bleached quartz grains, the two studies performed by the MNHN and BRGM teams show clearly that the sedimentary environments from the clayey unit D2, and the sandy units D1 and I, were simply not suitable to completely reset the ESR signals of the Al and Ti-Li centres. In contrast, the Ti$\mathrm{H}$ centre provides age estimates that are in agreement with the ESR/U-series results. This demonstrates the great potential of this centre to date late Middle Pleistocene deposits, which is consistent with previous observations by Duval et al. (2017). A multiple centre approach seems therefore indispensable when dating this type of fluvio-estuarine sediment, even when the sedimentological characteristics of the sediments seem initially quite suitable for an ESR study (as it was the case for the Tourville D1 and I units). Similar observations have been recently made on fluvial deposits from Spain (Duval et al., 2017; Méndez-Quintas et al., 2018), Italy (Pereira et al., 2015, 2018; Voinchet et al., this issue) or France (Duval et al., submitted).

Despite some (expected) discrepancies related to the independent use of parameters and approaches by the different teams involved in this multi-laboratory study, the whole set of ESR and ESR/U-series data collected at Tourville-la-Rivière locality consistently correlates stratigraphic levels D1 to I and associated human occupation to MIS7.

\section{Acknowledgments}

For the CENIEH-RSES team, the ESR/U-series study was initially funded by the project CGL2010-16821 from the Spanish Ministry of Science and Innovation and the Australian Research Council DP110101415. Aspects of this research have been covered by the ARC Future Fellowship Grant FT150100215. The authors thank Carlos Saiz and Verónica Guilarte, CENIEH, for their helpful contribution during sample preparation and ESR measurements. They thank also the two anonymous referees for their comments and suggestions that have greatly improved the manuscript.

The MNHN study is part of an ANR (Agence National pour la Recherche n²010 BLANC 200601 - coordinated by M.H. Moncel and D. Schreve) project. The MNHN team thanks Sylvie Coutard and Patrick Auguste for helpful discussion and the French Ministry of Culture for the financial support of PCR "les premiers hommes en Normandie" (coordinated by D. Cliquet). The ESR and mobile gamma-ray spectrometers of the French National Museum of Natural History were bought with the financial support of the 'Sesame île-de-France' program and the 'Région Centre' respectively.

The BRGM analyses were performed within a research project REGOMETH (PDR13DGR33). We thank also Mr Rozier, Denis and Lévêque (CBN) for the authorization of access to the Tourville Quarry.

\section{$\underline{\text { References }}$}

Adamiec, G., Aitken, M., 1998. Dose-rate conversion factor: update. Ancient TL 16, 37-50.

Auguste P., 2009 - Evolution des peuplements mammaliens en Europe du nord-ouest durant le Pléistocène moyen et supérieur. Le cas de la France septentrionale. Quaternaire, 20, 527-550

Bahain, J.-J., Falguères, C., Shao, Q., Tombret, O., Duval, M., Dolo, J.-M., 2015. La datation ESR/U-Th de restes paléontologiques, un outil pour estimer le degré de remaniement des niveaux archéologiques? Quaternaire, 26, 213-223

Bahain, J.-J., Falguères, C., Laurent, M., Shao, Q., Dolo, J.-M. Garcia, T., Douville, E., Frank, N., Monnier, J.-L., Hallegouët, B., Laforge, M., Huet, B., Auguste, P., Liouville, M., Serre, F., Gagnepain, J., 2012. ESR and ESR/U-series dating study of several middle palaeolithic sites of Pléneuf-Val-André (Brittany, France): Piégu, Les Vallées and Nantois. Quaternary Geochronology, 10, 424-429

Bahain, J.J., Yokoyama, Y., Falguères, C., Sarcia, M.N., 1992. ESR dating of tooth enamel: a comparison with K-Ar dating. Quaternary Science reviews, 11, 245-250.

Balescu, S., Lamothe, M., Lautridou, J.-P., 1997 - Luminescence evidence for two Middle Pleistocene interglacial events at Tourville, northwestern France. Boreas, 26, 61-72.

Beerten, K. and Stesmans, A. (2006). The use of Ti centers for estimating burial doses of single quartz grains: A case study from an aeolian deposit -2Ma old. Radiation Measurements 41(4): 418-424.

Bemilli, C. 2010. Les restes fauniques : presentation du corpus et méthodologie, In: Cliquet, D., (dir), 2010 Tourville-la-Rivière, Seine-Maritime. Carrières et ballastières de Normandie : La Fosse-Marmitaine. Section BD n² 24 à 30 et 32. INRAP Grand-Ouest, Caen, 105 p (unpublished). 
Bemilli, C., 2014. Les restes fauniques : presentation du corpus et méthodologie, In: Faivre, J.-Ph., (dir), 2014 Tourville-la-Rivière, La Fosse-Marmitaine: une fenêtre sur la vallée de la Seine au cours du Pléistocène moyen récent, INRAP Grand-Ouest, Grand-Quevilly, $357 \mathrm{p}$ (unpublished).

Brennan, B. J., 2003, Beta doses to spherical grains. Radiation Measurements 37, 299-303.

Brennan, B.J, Lyons, R, Phillips, S. 1991. Attenuation of alpha particle track dose for spherical grains. Nuclear Tracks Radiational Measurements 18, 249-253.

Brennan, B.J., Rink, W.J., McGuirl, E.L., Schwarcz, H.P., Prestwich, W.V., 1997. Beta doses in tooth enamel by "One Group" theory and the Rosy ESR dating software. Radiation Measurements 27, 307-314.

Chauhan, P. R., Bridgland, D. R., Moncel, M.-H., Antoine, P., Bahain, J.-J., Briant, R., Cunha, P., Despriée, J., Limondin-Lozouet, N., Locht, J.-L., Martins, A., Schreve, D. C., Shaw, A.D., Voinchet, P., Westaway, R., White, M. J., White, T. S., 2017. Fluvial deposits as an archive of early human activity: progress during the 20 years of the Fluvial Archives Group. Quaternary Science Reviews, 166, 114-149

Cliquet, D., (dir), 2010 - Tourville-la-Rivière, Seine-Maritime. Carrières et ballastières de Normandie : La FosseMarmitaine. Section BD n² 24 à 30 et 32. INRAP Grand-Ouest, Caen, 105 p (unpublished).

Cordier, S., Harmand, D., Lauer, T., Voinchet, P., Bahain, J.-J., Frechen M., 2012. Geochronological reconstruction of the Pleistocene evolution of the Sarre valley (France and Germany) using OSL and ESR dating techniques. Geomorphology, 165-166, 91-106

Dolo, J.-M., Lecerf, N., Mihajlovic, V., Falguères, C., Bahain, J.-J., 1996. Contribution of ESR dosimetry for irradiation of geological and archaeological samples with a 60-Co panoramic source, Applied Radiation and Isotopes 47, 1419-1421.

Dirks, P.H.G.M., Roberts, E.M., Hilbert-Wolf, H., Kramers, J.D., Hawks, J., Dosseto, A., Duval, M., Elliott, M., Evans, M., Grün, R., Hellstrom, J., Herries, A.I.R., Joannes-Boyau, R., Makhubela, T.V., Placzek, C.J., Robbins, J., Spandler, C., Wiersma, J., Woodhead, J. and Berger, L.R. (2017). The age of Homo naledi and associated sediments in the Rising Star Cave, South Africa. eLife 6: e24231.

Duval, M. (2012). Dose response curve of the ESR signal of the Aluminum centre in quartz grains extracted from sediment. Ancient TL 30(2): 1-9.

Duval, M. (2015). Electron Spin Resonance (ESR) Dating of Fossil Tooth Enamel. Encyclopedia of Scientific Dating Methods. W. J. Rink and J. W. Thompson, Springer Netherlands: pp 239-246.

Duval, M., Arnold L.J., Guilarte V., Demuro M., Santonja M, Pérez-González, A., 2017. Electron spin resonance dating of optically bleached quartz grains from the Middle Palaeolithic site of Cuesta de la Bajada (Spain) using the multiple centres approach. Quaternary Geochronology 37, 82-96.

Duval, M., Grün, R., Falguères, C., Bahain, J.J., Dolo, J.M., 2009. ESR dating of Lower Pleistocene fossil teeth: Limits of the single saturating exponential (SSE) function for the equivalent dose determination. Radiation Measurements 44, 477-482.

Duval, M., Grün, R., Parés, J.M., Martín-Francés, L., Campaña, I., Rosell, J., Shao, Q., Arsuaga, J.L., Carbonell, E. and Bermúdez de Castro, J.M. (2018). The first direct ESR analysis of a hominin tooth from Atapuerca Gran Dolina TD-6 (Spain) supports the antiquity of Homo antecessor. Quaternary Geochronology 47, 120-137.

Duval, M., Guilarte, V., 2015. ESR dosimetry of optically bleached quartz grains extracted from Plio-quaternary sediment: evaluating some key aspects of the ESR signal associated to the Ti-centre. Radiation Measurement 78, 28-41

Duval M., Voinchet P., Arnold L.J., Parés J.M., Minnella W., Guilarte V., Demuro M., Falguères C., Bahain J.-J. \& Despriée J. (submitted). A multi-technique dating study sheds new light on the chronology of two Lower Palaeolithic sites of the Middle Loire Basin, France: Lunery-la Terre-des-Sablons and Brinay-la Noira. Submitted to Quaternary International.

Faivre, J.-P., Maureille, B., Bayle, P., Crevecoeur, I., Duval, M., Grün, R., Bemilli, C., Bonilauri, S., Coutard, S., Bessou, M., Limondin-Lozouet, N., Cottard, A., Deshayes, T., Douillard, A., Henaff, X., Pautret-Homerville, C., Kinsley, L., Trinkaus, E., 2014 - Middle Pleistocene human remains from Tourville-la-Rivière (Normandy, France) and their archaeological context. PlosOne, 9 (10), e104111.

Falguères, C., Bahain, J.-J., Saleki, H., 1997. U-series and ESR dating of teeth from Acheulian and Mousterian levels at La Micoque (Dordogne, France). Journal of Archaeological Science, 24, 537-545

Falguères, C., Bahain, J.-J., Yokoyama, Y., Arsuaga, J.L., Bermudez De Castro, J.M., Carbonell, E., Bischoff, J.L., Dolo, J.M., 1999. Earliest humans in Europe: the age of TD6 Gran Dolina, Atapuerca, Spain. Journal of 
Human Evolution, 37, 343-352.

Forman, S. L., J. Pierson and K. Lepper 2000. Luminescence Geochronology. Quaternary Geochronology: methods and applications. J. Sowers, J. Noller and L. WR. Washington, DC, American Geophysical Union: 157-176.

Grün, R, Katzenberger-Apel, O., 1994. An alpha irradiator for ESR dating. Ancient TL 12, 35-38.

Grün, R. 2000a. An alternative for model for open system U-series/ESR age calculations: (closed system Useries)-ESR, CSUS-ESR. Ancient TL 18, 1-4.

Grün, R. (2000b). Methods of dose determination using ESR spectra of tooth enamel. Radiation Measurements 32(5-6): 767-772.

Grün, R., 2009. The DATA program for the calculation of ESR age estimates on tooth enamel. Quaternary Geochronology 4, 231-232.

Grün, R., Schwarcz, H.P., Chadam, J.M., 1988. ESR dating of tooth enamel: coupled correction for U-uptake and U-series disequilibrium. Nuclear Tracks and Radiation Measurements, 14, 237-241.

Grün, R., S. Eggins, L. Kinsley, H. Moseley and M. Sambridge (2014). Laser ablation U-series analysis of fossil bones and teeth. Palaeogeography, Palaeoclimatology, Palaeoecology 416: 150-167.

Guérin, G., Mercier, N., Adamiec, G., 2011. Dose-rate conversion factors: update. Ancient TL 29, 5-8.

Jamet, G., 2015. Réponses sédimentaires d'un bassin versant côtier aux variations glacio-eustatiques et au soulèvement plio-quaternaire : l'exemple du bassin versant côtier de la baie de Seine (Seine, Touques et Dives). PhD thesis, University of Caen, 418p (unpublished)

Kreutzer, S., Duval, M., Bartz, M., Bertran, P., Bosq, M., Eynaud, F., Verdin, F. and Mercier, N. (2018). Deciphering long-term coastal dynamics using IR-RF and ESR dating: a case study from Médoc, south-west France. Quaternary Geochronology 48: 108-120.

Lautridou, J.-P., 1985. Le cycle périglaciaire pléistocène en Europe du Nord-Ouest et plus particulièrement en Normandie. State doctorate thesis, Centre de Géomorphologie du CNRS éd., Caen, 907 p.

Liritzis, I., Stamoulis, K., Papachristodoulou, C. and loannides, K. (2013). A re-evaluation of radiation dose-rate conversion factors. Mediterranean Archaeology and Archaeometry 13(3): 1-15.

Ludwig, K. R., 2003. Isoplot 3.0, a geochronological toolkit for Microsoft Excel. Berkeley Geochronology Centre Special Publication, 4, 71p

Marsh, R.E., 1999. Beta-gradient isochrons using electron paramagnetic resonance: Towards a new dating method in archaeology. MSc thesis, McMaster University, Hamilton.

Méndez-Quintas, E., Santonja, M., Pérez-González, A., Duval, M., Demuro, M., Arnold, L. J., 2018. First evidence of an extensive Acheulean large cutting tool accumulation in Europe from Porto Maior (Galicia, Spain). Scientific Reports 8:3082.

Mercier, N, Falguères, C, 2007. Field gamma dose-rate measurement with a Nal(TI) detector: re-evaluation of the "threshold" technique. Ancient TL Vol. 25 No.1

Occhietti, S., Pichet, P., Rheault, L., 1987. Résultats préliminaires d'aminochronologie moyenne et basse vallée de la Seine in Lautridou J.-P., La Normandie, Guide d'excursion de l'Association Française pour l'Étude du Quaternaire, additif, $19 \mathrm{p}$.

Pereira, A., Nomade, S., Moncel, M.-H., Voinchet, P., Bahain, J.-J., Biddittu, I., Falguères, C., Giaccio, B., Manzi, G., Parenti, F., Scardia, G., Scao, V., Sottili, G., Vietti, A., 2018. Geochronological evidences of a MIS 11 to MIS 10 age for several key Acheulian sites from the Frosinone province (Latium, Italy): Archaeological implications. Quaternary Science Reviews, 187, 112-129

Pereira, A., Nomade, S., Voinchet, P., Bahain, J.-J., Falguères, C., Garon, H., Lefèvre, D., Raynal, J.-P., Scao, V., Piperno, M., 2015. The earliest securely dated hominid fossil in Italy and evidences of Acheulian human occupations during glacial MIS 16 at Notarchirico (Venosa, Basilicata, Italy). Journal of Quaternary Science, 30 (7), 639-650

Prescott, J.R., Hutton, J. T., 1994. Cosmic ray contributions to dose rates for Luminescence and ESR Dating: Large depths and long-term time. Radiation Measurements. 23, 497-500

Prescott, J.R., Hutton, J.T., 1988. Cosmic ray and gamma ray dosimetry for TL and ESR. Nuclear Tracks and Radiation Measurements 14: 223-227.

Sahnouni, M., Parés, J.M., Duval, M., Cáceres, I., Harichane, Z., van der Made, J., Pérez-González, A., 
Abdessadok, S., Kandi, N., Derradji, A., Medig, M., Boulaghraif, K. and Semaw, S. (2018). 1.9-million- and 2.4-million-year-old artifacts and stone tool-cutmarked bones from Ain Boucherit, Algeria. Science 362(6420): 1297-1301.

Schwarcz, H. P., Grün, R., 1988. ESR dating of level L2/3 at La Micoque, Dordogne (France): Excavation of Debénath and Rigaud. Geoarchaeology 3-4, 293-296.

Shao, Q., Bahain, J.-J., Falguères, C., Dolo, J.-M., Garcia, T., 2012. A new U-uptake model for combined ESR/Useries dating of tooth enamel. Quaternary Geochronology 10: 406-411.

Shao, Q., Bahain, J.J., Dolo, J.M., Falguères, C., 2014. Monte Carlo approach to calculate US-ESR ages and their uncertainties. Quaternary Geochronology 22, 99-106.

Shao, Q., Chadam, J., Grün, R., Falguères, C., Dolo., J.-M., Bahain, J.-J., 2015. The mathematical basis for the USESR dating method. Quaternary Geochronology 30: 1-8.

Stremme, H.E., 1985. Altersbestimmung und Palaoboden in der Quatarstratigraphie. Bulletin de I'Association Française pour I 'Etude du Quaternaire, 2-3, pp.159-166.

Tissoux, H., Falguères, C., Voinchet, P., Toyoda, S., Bahain, J.J. and Despriée, J. (2007). Potential use of Ti-center in ESR dating of fluvial sediment. Quaternary Geochronology 2(1-4): 367-372.

Tissoux, H., Toyoda, S., Falguères, C., Voinchet, P., Takada, M., Bahain, J.-J., Despriée, J., 2008. ESR dating of sedimentary quartz from two Pleistocene deposits using Al and Ti-centres. Geochronometria 30, $23-31$.

Tissoux, H., P. Voinchet, F. Lacquement, F. Prognon, D. Moreno, C. Falguères, J.-J. Bahain and S. Toyoda (2012). Investigation on non-optically bleachable components of ESR aluminium signal in quartz. Radiation Measurements 47(9): 894-899.

Toyoda, S. (2015). Paramagnetic lattice defects in quartz for applications to ESR dating. Quaternary Geochronology 30, Part B: 498-505.

Toyoda, S., Falguères C., 2003. The method to represent the ESR signal intensity of the aluminium hole centre in quartz for the purpose of dating. Advances in ESR applications, 20, 7-10.

Toyoda, S., Voinchet, P., Falguères, C., Dolo, J.-M., Laurent, M., 2000. Bleaching of ESR signals by the sunlight: a laboratory experiment for establishing the ESR dating of sediments. Applied Radiation and Isotopes 52, 1357-1362,

Voinchet, P., C. Falguères, M. Laurent, S. Toyoda, J. J. Bahain and J. M. Dolo (2003). Artificial optical bleaching of the Aluminium center in quartz implications to ESR dating of sediments. Quaternary Science Reviews 22(10-13): 1335-1338.

Voinchet, P., Bahain, J.-J., Falguères, C., Laurent, M., Dolo, J.-M., Despriée, J., Gageonnet R., 2004. ESR dating of quartz extracted from Quaternary sediments: Application to fluvial terraces system of Northern France. Quaternaire, 15, 135-141.

Voinchet, P., Toyoda, S., Falguères, C., Hernandez, M., Tissoux, H., Bahain, J.-J., 2015. ESR residual dose in quartz modern samples, an investigation into environmental dependence. Quaternary Geochronology, 30, 506-512

Voinchet P., Falguères C., Pereira A., Nomade S., Biddittu I., Pipperno M., Bahain J.-J. (this issue). ESR dating applied to optically bleached quartz-a comparison with 40Ar/39Ar chronologies on Italian Middle Pleistocene sequences.

Yokoyama, Y., Falguères, C., Quaegebeur, J.P., 1985. ESR dating of quartz from Quaternary sediments: first attempt. Nuclear tracks 10, 921-928.

\section{Figure caption}

Figure 1 - Location of the Tourville-la-Rivière site, Northern France, in the Seine valley terrace system (after Jamet, 2015)

Figure 2 - Overview of the sedimentary sequence at Tourville-la-Rivière, including stratigraphic subdivision, biomarkers identified, numerical dating results available before the recent ESR/U-series and ESR studies, and palaeoenvironmental interpretation (after Jamet, 2015)

Figure 3 - Sampling location or the analyzed teeth and sediments from the Tourville-la-Rivière site

Figure 4 - Sampling location of the 2013 sediments from Tourville-la Rivière analyzed by the BRGM team. 
Figure 5 - ESR/U-series data obtained on the Tourville-la Rivière teeth analyzed by the CENIEH-RSES and MNHN teams. A) Equivalent dose values; B) U-series data; C) U-content of the dental tissues; D) ESR/U-series (US and CS-US) and corresponding age density probability plots.

Figure 6 - ESR ages obtained on the Tourville-la Rivière sediments analyzed by the MNHN and BRGM teams using different ESR centres. The grey band corresponds to the MIS 7 time range.

\section{Table caption}

647 Table 1 - Comparison of the analytical procedures used by the CENIEH-RSES and MNHN teams for the 648 combined U-series/ESR dating of fossil teeth.

649 Table 2 - Comparison of the analytical protocols used by the MNHN and BRGM teams for the ESR dating of the 650 Tourville sediments.

651 Table 3: U-series and ESR data obtained by the CENIEH-RSES team (modified from Faivre et al., 2014).

652 Table 4 - U-series and ESR data obtained by the MNHN team. Analytical uncertainties are given with $\pm 1 \sigma . *$ The depth was estimated from the chronostratigraphic interpretation of Jamet (2015). Table 5- Radioelement contents, equivalent doses, bleaching rate, dose rate contributions and ESR ages obtained for the sediments of the Tourville-la-Rivière D1 and D2 levels dated by the MNHN team. The bleaching coefficient represents the relative difference between the ESR intensities of the natural and bleached aliquots. Analytical uncertainties are given with $\pm 1 \sigma$.

658 Table 6 - Radioelement contents, equivalent doses, bleaching rate, dose rates contributions and ESR ages obtained for the sediments of the Tourville-la-Rivière D1 and I levels analyzed by the BRGM team. Analytical uncertainties are given with $\pm 1 \sigma$.

661 Table 7 - Comparison of the equivalent dose values obtained with or without use of Duval and Grün (2016)'s 


\begin{tabular}{|c|c|c|c|c|c|c|c|c|c|c|c|c|}
\hline \multirow{2}{*}{ Sample } & \multirow{2}{*}{ Tissue } & \multirow{2}{*}{$\underset{(p p m)}{U}$} & \multirow{2}{*}{${ }^{234} U /{ }^{238} U$} & \multirow{2}{*}{${ }^{230} \mathrm{Th} /{ }^{238} \mathrm{U}$} & \multirow{2}{*}{$\begin{array}{l}\text { Apparent U- } \\
\text { series age } \\
\text { (ka) }\end{array}$} & \multirow{2}{*}{$\begin{array}{c}\text { Initial enamel } \\
\text { Thickness } \\
(\mu \mathrm{m})\end{array}$} & \multirow{2}{*}{$\begin{array}{c}\text { Removed } \\
\text { thickness } \\
\quad(\mu \mathrm{m})\end{array}$} & \multirow{2}{*}{$\begin{array}{l}\text { Depth } \\
\text { (m) }\end{array}$} & \multicolumn{3}{|c|}{$\begin{array}{l}\text { Sediment radioelement } \\
\text { contents }\end{array}$} & \multirow{2}{*}{$\begin{array}{l}D_{E} \\
(G y)\end{array}$} \\
\hline & & & & & & & & & $\begin{array}{c}U \\
(p p m)\end{array}$ & $\begin{array}{c}\text { Th } \\
\text { (ppm) }\end{array}$ & $\begin{array}{c}K \\
(\%)\end{array}$ & \\
\hline \multirow{2}{*}{$\mathrm{T} 1$} & enamel & $\begin{array}{c}0.39 \\
\pm 0.00\end{array}$ & $\begin{array}{c}1.2266 \\
\pm 0.0483\end{array}$ & $\begin{array}{c}0.6211 \\
\pm 0.0331\end{array}$ & 75.1 & \multirow{2}{*}{$\begin{array}{r}1160 \\
\pm 116\end{array}$} & $(1): 100 \pm 10$ & \multirow{2}{*}{$\begin{array}{l}21 \\
\pm 3\end{array}$} & \multirow{2}{*}{$\begin{array}{c}1.11 \\
\pm 0.02\end{array}$} & \multirow{2}{*}{$\begin{array}{c}4.09 \\
\pm 0.02\end{array}$} & \multirow{2}{*}{$\begin{array}{c}0.67 \\
\pm 0.02\end{array}$} & \multirow{2}{*}{$\begin{array}{l}121 \\
\pm 2\end{array}$} \\
\hline & dentine & $\begin{array}{l}19.68 \\
\pm 0.12 \\
\end{array}$ & $\begin{array}{r}1.2366 \\
\pm 0.0127 \\
\end{array}$ & $\begin{array}{c}0.7922 \\
\pm 0.0471 \\
\end{array}$ & 106.8 & & $(2): 110 \pm 11$ & & & & & \\
\hline \multirow{2}{*}{$\mathrm{T} 2$} & enamel & $\begin{array}{c}0.53 \\
\pm 0.02\end{array}$ & $\begin{array}{c}1.2110 \\
\pm 0.0882\end{array}$ & $\begin{array}{c}1.0357 \\
\pm 0.1012\end{array}$ & 189.0 & \multirow{2}{*}{$\begin{array}{r}1010 \\
\pm 101\end{array}$} & $(1): 110 \pm 11$ & \multirow{2}{*}{$\begin{array}{r}21 \\
\pm 3\end{array}$} & \multirow{2}{*}{$\begin{array}{c}1.11 \\
\pm 0.02\end{array}$} & \multirow{2}{*}{$\begin{array}{r}4.09 \\
\pm 0.02\end{array}$} & \multirow{2}{*}{$\begin{array}{c}0.67 \\
\pm 0.02\end{array}$} & \multirow{2}{*}{$\begin{array}{l}175 \\
\pm 2\end{array}$} \\
\hline & dentine & $\begin{array}{l}28.49 \\
\pm 0.97\end{array}$ & $\begin{array}{r}1.3172 \\
\pm 0.0032 \\
\end{array}$ & $\begin{array}{r}1.0415 \\
\pm 0.0103 \\
\end{array}$ & 154.0 & & $(2): 100 \pm 10$ & & & & & \\
\hline \multirow{2}{*}{ T3 } & enamel & $\begin{array}{c}0.42 \\
\pm 0.11\end{array}$ & $\begin{array}{c}1.2097 \\
\pm 0.0383\end{array}$ & $\begin{array}{c}0.7048 \\
\pm 0.1833\end{array}$ & 92.3 & \multirow{2}{*}{$\begin{array}{l}1300 \\
\pm 130\end{array}$} & (1): $90 \pm 9$ & \multirow{2}{*}{$\begin{array}{r}20 \\
\pm 3\end{array}$} & \multirow{2}{*}{$\begin{array}{c}0.88 \\
\pm 0.02 \\
\end{array}$} & \multirow{2}{*}{$\begin{array}{c}3.73 \\
\pm 0.02\end{array}$} & \multirow{2}{*}{$\begin{array}{c}0.72 \\
\pm 0.02\end{array}$} & \multirow{2}{*}{$\begin{array}{l}142 \\
\pm 4\end{array}$} \\
\hline & dentine & $\begin{array}{r}28.19 \\
\pm 1.64 \\
\end{array}$ & $\begin{array}{c}1.2468 \\
\pm 0.0070 \\
\end{array}$ & $\begin{array}{r}0.8435 \\
\pm 0.0155 \\
\end{array}$ & 116.8 & & (2): $120 \pm 12$ & & & & & \\
\hline \multirow{2}{*}{$\mathrm{T} 4$} & enamel & $\begin{array}{c}0.41 \\
\pm 0.14\end{array}$ & $\begin{array}{c}1.2398 \\
\pm 0.0471\end{array}$ & $\begin{array}{c}1.3390 \\
\pm 0.1092\end{array}$ & 656.2 & 900 & (1): $110 \pm 11$ & & 1.47 & 3.52 & 0.67 & 165 \\
\hline & dentine & $\begin{array}{r}24.10 \\
\pm 1.97 \\
\end{array}$ & $\begin{array}{c}1.3209 \\
\pm 0.0102 \\
\end{array}$ & $\begin{array}{r}1.0818 \\
\pm 0.0175 \\
\end{array}$ & 165.5 & \pm 90 & $(2): 90 \pm 9$ & \pm 3 & \pm 0.02 & \pm 0.02 & \pm 0.02 & \pm 2 \\
\hline & enamel & $\begin{array}{c}0.71 \\
\pm 0.27\end{array}$ & $\begin{array}{c}1.3082 \\
\pm 0.0475\end{array}$ & $\begin{array}{c}1.2751 \\
\pm 0.0742\end{array}$ & 265.7 & 970 & (1): $50 \pm 5$ & 21 & 1.47 & 3.52 & 0.67 & 155 \\
\hline 15 & dentine & $\begin{array}{r}23.04 \\
\pm 0.93 \\
\end{array}$ & $\begin{array}{c}1.3608 \\
\pm 0.0084 \\
\end{array}$ & $\begin{array}{r}1.2050 \\
\pm 0.0585 \\
\end{array}$ & 196.1 & \pm 97 & $(2): 80 \pm 8$ & \pm 3 & \pm 0.02 & \pm 0.02 & \pm 0.02 & \pm 4 \\
\hline & enamel & $\begin{array}{c}0.41 \\
\pm 0.12\end{array}$ & $\begin{array}{c}1.1931 \\
\pm 0.0360\end{array}$ & $\begin{array}{c}0.8108 \\
\pm 0.0746\end{array}$ & 118.8 & & $(1): 30 \pm 3$ & & & & & \\
\hline T6 & dentine & $\begin{array}{l}27.85 \\
\pm 2.43\end{array}$ & $\begin{array}{c}1.2029 \\
\pm 0.0069\end{array}$ & $\begin{array}{c}0.8059 \\
\pm 0.0067\end{array}$ & 115.7 & $\begin{array}{r}890 \\
\pm 89\end{array}$ & & $\begin{array}{l}21 \\
\pm 3\end{array}$ & $\begin{array}{c}0.88 \\
\pm 0.02\end{array}$ & $\begin{array}{c}3.73 \\
\pm 0.02\end{array}$ & $\begin{array}{c}0.72 \\
\pm 0.02\end{array}$ & $\begin{array}{l}153 \\
\pm 4\end{array}$ \\
\hline & cementum & $\begin{array}{r}29.98 \\
\pm 6.69 \\
\end{array}$ & $\begin{array}{r}1.2836 \\
\pm 0.0059 \\
\end{array}$ & $\begin{array}{c}0.8287 \\
\pm 0.0326 \\
\end{array}$ & 107.5 & & & & & & & \\
\hline & enamel & $\begin{array}{c}0.49 \\
\pm 0.18\end{array}$ & $\begin{array}{c}1.2791 \\
\pm 0.0578\end{array}$ & $\begin{array}{c}0.7844 \\
\pm 0.1109\end{array}$ & 99.1 & & (1): $20 \pm 2$ & & & & & \\
\hline $\mathrm{T7}$ & dentine & $\begin{array}{r}29.90 \\
\pm 1.15\end{array}$ & $\begin{array}{c}1.2096 \\
\pm 0.0080\end{array}$ & $\begin{array}{c}0.7702 \\
\pm 0.0055\end{array}$ & 106.2 & $\begin{array}{l}1050 \\
\pm 105\end{array}$ & (2). $60+6$ & $\begin{array}{l}21 \\
\pm 3\end{array}$ & $\begin{array}{c}0.88 \\
\pm 0.02\end{array}$ & $\begin{array}{c}3.73 \\
\pm 0.02\end{array}$ & $\begin{array}{c}0.72 \\
\pm 0.02\end{array}$ & $\begin{array}{l}164 \\
\pm 4\end{array}$ \\
\hline & cementum & $\begin{array}{r}37.26 \\
\pm 1.27 \\
\end{array}$ & $\begin{array}{c}1.3047 \\
\pm 0.0105 \\
\end{array}$ & $\begin{array}{c}0.7773 \\
\pm 0.0124 \\
\end{array}$ & 94.5 & & $(2): 60 \pm 6$ & & & & & \\
\hline & enamel & $\begin{array}{c}0.82 \\
\pm 0.37\end{array}$ & $\begin{array}{c}1.3203 \\
\pm 0.0437\end{array}$ & $\begin{array}{c}1.1941 \\
\pm 0.1182\end{array}$ & 209.8 & 840 & (1): $40 \pm 4$ & 20 & 0.87 & 3.77 & 0.72 & 254 \\
\hline T8 & dentine & $\begin{array}{r}17.76 \\
\pm 0.46 \\
\end{array}$ & $\begin{array}{c}1.3777 \\
\pm 0.0089 \\
\end{array}$ & $\begin{array}{c}1.3479 \\
\pm 0.0132 \\
\end{array}$ & & \pm 84 & $(2): 60 \pm 6$ & \pm 3 & \pm 0.02 & \pm 0.02 & \pm 0.02 & \pm 4 \\
\hline
\end{tabular}

\begin{tabular}{|c|c|c|c|c|c|c|c|c|c|}
\hline Sample & $\begin{array}{l}\text { Dental } \\
\text { tissue }\end{array}$ & $\begin{array}{c}\text { p U-uptake } \\
\text { parameter (a.u.) }\end{array}$ & $\begin{array}{l}D_{\text {internal }} \\
(\mu G y / a)\end{array}$ & $\begin{array}{l}D_{\text {Bdentine }} \\
(\mu G y / a)\end{array}$ & $\begin{array}{l}\text { D }_{\text {Bsediment }} \\
(\mu \mathrm{Gy} / \mathrm{a})\end{array}$ & $\begin{array}{l}D_{(\gamma+\cos m)} \\
(\mu G y / a)\end{array}$ & $\begin{array}{c}D_{a} \\
(\mu G y / a)\end{array}$ & $\begin{array}{l}\text { ESR-U-series } \\
\text { age (ka) }\end{array}$ & $\begin{array}{l}\text { CS-US-ESR } \\
\text { age (ka) }\end{array}$ \\
\hline T1 & $\begin{array}{l}\text { enamel } \\
\text { dentine }\end{array}$ & $\begin{array}{l}-0.09 \pm 0.27 \\
-0.51 \pm 0.20\end{array}$ & $56 \pm 16$ & $133 \pm 33$ & $61 \pm 11$ & $405 \pm 55$ & $656 \pm 67$ & $184+26-19$ & $201 \pm 25$ \\
\hline T2 & $\begin{array}{l}\text { enamel } \\
\text { dentine }\end{array}$ & $\begin{array}{l}-0.93 \pm 0.06 \\
-0.93 \pm 0.06\end{array}$ & $185 \pm 33$ & $344 \pm 63$ & $68 \pm 12$ & $405 \pm 52$ & $1003 \pm 88$ & $174+17-14$ & $188 \pm 21$ \\
\hline T3 & $\begin{array}{l}\text { enamel } \\
\text { dentine }\end{array}$ & $\begin{array}{l}-0.12 \pm 0.50 \\
-0.49 \pm 0.14\end{array}$ & $71 \pm 40$ & $173 \pm 36$ & $55 \pm 10$ & $381 \pm 48$ & $680 \pm 72$ & $208 \pm 28-22$ & $236 \pm 29$ \\
\hline & & $+x$ & & & & & Weighted mean & $194+14-11$ & $211 \pm 15$ \\
\hline
\end{tabular}


ACCEPTED MANUSCRIPT

\begin{tabular}{|c|c|c|c|c|c|c|c|c|c|c|c|c|}
\hline Sample & $\begin{array}{l}\text { Dental } \\
\text { tissue }\end{array}$ & \multicolumn{2}{|c|}{ U (ppm) } & ${ }^{234} U /{ }^{238} U$ & ${ }^{230} \mathrm{Th} /{ }^{238} \mathrm{U}$ & $\begin{array}{l}\text { Apparent } \\
\text { U-series } \\
\text { age (ka) }\end{array}$ & ${ }^{222} \mathrm{Rn} /{ }^{230} \mathrm{Th}$ & & $\begin{array}{c}\text { Initial } \\
\text { enamel } \\
\text { thickness } \\
(\mu \mathrm{m})\end{array}$ & $\begin{array}{c}\text { Removed } \\
\text { thickness } \\
\quad(\mu \mathrm{m})\end{array}$ & $\begin{array}{l}\text { Mean depth } \\
(\mathrm{m})^{*}\end{array}$ & $\begin{array}{l}D_{e} \\
\text { (Gy) }\end{array}$ \\
\hline \multirow{2}{*}{ TVL 157} & \multirow{2}{*}{$\begin{array}{l}\text { enamel } \\
\text { dentine }\end{array}$} & \multicolumn{2}{|c|}{$0.594 \pm 0.024$} & $1.441 \pm 0.069$ & $1.222 \pm 0.101$ & 174 & 0.334 & \multirow{2}{*}{\multicolumn{2}{|c|}{$959 \pm 17$}} & \multirow{2}{*}{$\begin{array}{l}\text { (1) } 21 \pm 3 \\
\text { (2) } 74 \pm 9\end{array}$} & \multirow[b]{2}{*}{$14 \pm 3$} & \multirow{2}{*}{$220.08 \pm 2.33$} \\
\hline & & \multicolumn{2}{|c|}{$25.342 \pm 0.580$} & $1.306 \pm 0.026$ & $1.028 \pm 0.052$ & 153 & 0.366 & & & & & \\
\hline \multirow{2}{*}{ TVL 160} & \multirow{2}{*}{$\begin{array}{l}\text { enamel } \\
\text { dentine }\end{array}$} & \multirow{2}{*}{\multicolumn{2}{|c|}{$\begin{array}{c}0.402 \pm 0.016 \\
22.504 \pm 0.486\end{array}$}} & \multirow{2}{*}{$\begin{array}{l}1.313 \pm 0.060 \\
1.333 \pm 0.026\end{array}$} & $1.155 \pm 0.102$ & 195 & \multirow{2}{*}{\multicolumn{2}{|c|}{$\begin{array}{l}1.000 \\
0.340\end{array}$}} & \multirow{2}{*}{$1050 \pm 131$} & \multirow{2}{*}{$\begin{array}{c}\text { (1) } 28 \pm 3 \\
\text { (2) } 160 \pm 20\end{array}$} & \multirow{2}{*}{$14 \pm 3$} & \multirow{2}{*}{$207.72 \pm 2.72$} \\
\hline & & & & & $1.152 \pm 0.049$ & 186 & & & & & & \\
\hline \multirow{2}{*}{ TVL 219} & \multirow{2}{*}{$\begin{array}{l}\text { enamel } \\
\text { dentine }\end{array}$} & \multirow{2}{*}{\multicolumn{2}{|c|}{$\begin{array}{l}0.671 \pm 0.022 \\
31.541 \pm 0.636\end{array}$}} & \multirow{2}{*}{$\begin{array}{l}1.259 \pm 0.043 \\
1.274 \pm 0.022\end{array}$} & $0.993 \pm 0.081$ & 155 & \multirow{2}{*}{\multicolumn{2}{|c|}{$\begin{array}{l}0.405 \\
0.378\end{array}$}} & \multirow{2}{*}{$1027 \pm 128$} & \multirow{2}{*}{$\begin{array}{c}\text { (1) } 14 \pm 2 \\
\text { (2) } 167 \pm 21\end{array}$} & $14+3$ & $30454+249$ \\
\hline & & & & & $0.956 \pm 0.048$ & 140 & & & & & $14 \pm 3$ & $204.54 \pm 2.49$ \\
\hline TPY 022 & enamel & $0.490 \pm$ & .018 & $1.301 \pm 0.054$ & $1.106 \pm 0.094$ & 181 & 0.259 & & & (1) $68 \pm 9$ & & $20156+10$ \\
\hline (1) & dentine & $29.026 \pm$ & .741 & $1.261 \pm 0.028$ & $1.005 \pm 0.058$ & 159 & 0.293 & & & (2) $76 \pm 9$ & & 204.56 \\
\hline TPY 020 & enamel & $0.296 \pm$ & .014 & $1.409 \pm 0.076$ & $1.305 \pm 0.116$ & 217 & 0.258 & & $168+150$ & (1) $200 \pm 25$ & $11+2$ & $10132+502$ \\
\hline $1 K V 928$ & dentine & $19.976 \pm$ & .348 & $1.311 \pm 0.021$ & $1.053 \pm 0.083$ & 159 & 0.523 & & $68 \pm 159$ & (2) $148 \pm 18$ & $14 \pm 3$ & $191.33 \pm 5.82$ \\
\hline TVI 929(a) & enamel & $0.374 \pm$ & .013 & $1.236 \pm 0.047$ & $0.973 \pm 0.086$ & 155 & 0.247 & & $1200+150$ & (1) $112 \pm 14$ & $14+3$ & $19195+273$ \\
\hline | & dentine & $3.046 \pm$ & .067 & $1.263 \pm 0.025$ & $0.988 \pm 0.054$ & 153 & 1.000 & & & (2) $60 \pm 8$ & $14 \pm 0$ & 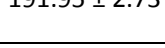 \\
\hline & Sediment $r$ & adioelemen & contents & Dental & p U-uptake & & $\mathbf{D}_{\alpha}$ & $D_{B}$ & $D_{(y+\cos m)}$ & & US-ESR age & CSUS- \\
\hline Sample & $U(p p m)$ & Th (ppm) & K (\%) & tissue & parameter (a.u.) & & $(\mu \mathrm{Gy} / \mathrm{a})$ & ( $\mu \mathrm{Gy} / \mathrm{a})$ & $(\mu \mathrm{Gy} / \mathrm{a})$ & $(\mu \mathrm{Gy} / \mathrm{a})$ & (ka) & $\begin{array}{c}\text { ESR age } \\
\text { (ka) }\end{array}$ \\
\hline TVI 157 & 1.072 & 4.005 & 0.894 & enamel & $-0.83 \pm 0.04$ & & 139 & 305 & 517 & 961 & 229 & 252 \\
\hline IVL 107 & \pm 0.086 & \pm 0.114 & \pm 0.014 & dentine & $-0.72 \pm 0.05$ & & \pm 27 & \pm 42 & \pm 29 & \pm 58 & \pm 13 & \pm 16 \\
\hline TVL 160 & 1.252 & 4.341 & 0.902 & enamel & $-0.91 \pm 0.03$ & & 100 & 294 & 517 & 911 & 228 & 239 \\
\hline IVL 100 & \pm 0.074 & \pm 0.099 & \pm 0.011 & dentine & $-0.88 \pm 0.03$ & & \pm 19 & \pm 44 & \pm 29 & \pm 56 & \pm 13 & \pm 12 \\
\hline TVI 219 & 1.293 & 3.807 & 0.853 & enamel & $-0.82 \pm 0.05$ & & 142 & 349 & 517 & 1008 & 203 & 223 \\
\hline IVL 219 & \pm 0.076 & \pm 0.102 & \pm 0.012 & dentine & $-0.73 \pm 0.05$ & & \pm 28 & \pm 55 & \pm 29 & \pm 61 & \pm 13 & \pm 14 \\
\hline TRY 923 & 1.065 & 3.716 & 0.837 & enamel & $-0.88 \pm 0.04$ & & 103 & 314 & 517 & 934 & 219 & 232 \\
\hline IRV 923 & \pm 0.063 & \pm 0.084 & \pm 0.010 & dentine & $-0.78 \pm 0.04$ & & \pm 21 & \pm 47 & \pm 29 & \pm 59 & \pm 13 & \pm 14 \\
\hline TRY 978 & 1.120 & 3.735 & 0.799 & enamel & $-0.93 \pm 0.03$ & & 75 & 176 & 517 & 768 & 249 & 268 \\
\hline IRV 928 & \pm 0.078 & \pm 0.103 & \pm 0.012 & dentine & $-0.69 \pm 0.05$ & & \pm 26 & \pm 39 & \pm 29 & \pm 55 & \pm 15 & \pm 15 \\
\hline TY/ 929/2) & 1.151 & 3.678 & 0.807 & enamel & $-0.74 \pm 0.04$ & & 65 & 271 & 517 & 853 & 225 & 240 \\
\hline IVL 929(a) & \pm 0.086 & \pm 0.114 & \pm 0.014 & dentine & $-0.73 \pm 0.05$ & & \pm 14 & \pm 43 & \pm 29 & \pm 54 & \pm 13 & \pm 13 \\
\hline & & & & & & & & & & Weigthed mean & $224 \pm 11$ & $241 \pm 11$ \\
\hline
\end{tabular}




\begin{tabular}{|c|c|c|c|c|c|c|c|c|c|c|c|c|}
\hline Sample & Level & U (ppm) & $\begin{array}{c}\text { Th } \\
\text { (ppm) }\end{array}$ & K (\%) & $\begin{array}{c}\text { Al } \\
\text { Bleaching } \\
\text { coefficient } \\
(\%)\end{array}$ & $\begin{array}{l}D_{e} \\
\text { (Gy) }\end{array}$ & $\begin{array}{c}D_{\alpha} \\
(\mu G y / a)\end{array}$ & $\begin{array}{c}D_{\beta} \\
(\mu G y / a)\end{array}$ & $\frac{\text { in situ } D_{y}}{(\mu G y / a)}$ & $\begin{array}{c}D_{\text {cosmic }} \\
(\mu G y / a)\end{array}$ & $\begin{array}{c}D_{a} \\
(\mu G y / a)\end{array}$ & $\begin{array}{l}\text { Age } \\
\text { (ka) }\end{array}$ \\
\hline Tourville 1 & D2 & $\begin{array}{c}1.014 \pm \\
0.074\end{array}$ & $\begin{array}{c}3.270 \pm \\
0.103\end{array}$ & $\begin{array}{c}0.748 \pm \\
0.012\end{array}$ & 44 & $\begin{array}{r}409 \\
\pm 56 \\
\end{array}$ & $\begin{array}{r}26 \\
\pm 1 \\
\end{array}$ & $\begin{array}{r}622 \\
\pm 17 \\
\end{array}$ & $\begin{array}{r}393 \\
\pm 20 \\
\end{array}$ & $\begin{array}{l}102 \\
\pm 5 \\
\end{array}$ & $\begin{array}{l}1144 \\
\pm 22 \\
\end{array}$ & $\begin{array}{r}358 \\
\pm 50 \\
\end{array}$ \\
\hline Tourville 2 & D2 & $\begin{array}{c}0.895 \pm \\
0.083\end{array}$ & $\begin{array}{c}3.133 \pm \\
0.114\end{array}$ & $\begin{array}{c}0.728 \pm \\
0.014\end{array}$ & 42 & $\begin{array}{r}398 \\
\pm 30 \\
\end{array}$ & $\begin{array}{r}24 \\
\pm 1\end{array}$ & $\begin{array}{r}595 \\
\pm 19\end{array}$ & $\begin{array}{r}418 \\
\pm 20\end{array}$ & $\begin{array}{l}102 \\
\pm 5\end{array}$ & $\begin{array}{l}1139 \\
\pm 50\end{array}$ & $\begin{array}{r}349 \\
\pm 30\end{array}$ \\
\hline Tourville 3 & D2 & $\begin{array}{c}0.993 \pm \\
0.086\end{array}$ & $\begin{array}{c}3.460 \pm \\
0.118\end{array}$ & $\begin{array}{c}0.756 \pm \\
0.014\end{array}$ & 49 & $\begin{array}{r}708 \\
\pm 87 \\
\end{array}$ & $\begin{array}{r}27 \\
\pm 1 \\
\end{array}$ & $\begin{array}{r}629 \\
\pm 20 \\
\end{array}$ & $\begin{array}{r}412 \\
\pm 20 \\
\end{array}$ & $\begin{array}{l}102 \\
\pm 5 \\
\end{array}$ & $\begin{array}{l}1170 \\
\pm 26 \\
\end{array}$ & $\begin{array}{r}605 \\
\pm 80 \\
\end{array}$ \\
\hline Tourville 4 & D2 & $\begin{array}{c}0.990 \pm \\
0.072\end{array}$ & $\begin{array}{c}3.567 \pm \\
0.099\end{array}$ & $\begin{array}{c}0.741 \pm \\
0.012 \\
\end{array}$ & 51 & $\begin{array}{r}1085 \\
\pm 76 \\
\end{array}$ & $\begin{array}{l}27 \\
\pm 1 \\
\end{array}$ & $\begin{array}{r}621 \\
\pm 17 \\
\end{array}$ & $\begin{array}{r}447 \\
\pm 20 \\
\end{array}$ & $\begin{array}{l}102 \\
\pm 5 \\
\end{array}$ & $\begin{array}{l}1198 \\
\pm 21 \\
\end{array}$ & $\begin{array}{r}906 \\
\pm 70 \\
\end{array}$ \\
\hline Tourville 5 & D1 & $\begin{array}{c}0.767 \pm \\
0.046\end{array}$ & $\begin{array}{c}1.677 \pm \\
0.057\end{array}$ & $\begin{array}{c}0.426 \pm \\
0.006\end{array}$ & 46 & $\begin{array}{r}246 \\
\pm 32 \\
\end{array}$ & $\begin{array}{r}16 \\
\pm 1 \\
\end{array}$ & $\begin{array}{r}370 \\
\pm 10 \\
\end{array}$ & $\begin{array}{r}260 \\
\pm 13 \\
\end{array}$ & $\begin{array}{r}89 \\
\pm 4 \\
\end{array}$ & $\begin{array}{r}736 \\
\pm 13 \\
\end{array}$ & $\begin{array}{r}334 \\
\pm 90 \\
\end{array}$ \\
\hline Tourville 6 & D1 & $\begin{array}{c}0.711 \pm \\
0.067\end{array}$ & $\begin{array}{c}1.978 \pm \\
0.080\end{array}$ & $\begin{array}{c}0.447 \pm \\
0.010\end{array}$ & 46 & $\begin{array}{r}295 \\
\pm 40 \\
\end{array}$ & $\begin{array}{r}18 \\
\pm 1 \\
\end{array}$ & $\begin{array}{r}389 \\
\pm 15 \\
\end{array}$ & $\begin{array}{r}260 \\
\pm 13 \\
\end{array}$ & $\begin{array}{r}89 \\
\pm 4 \\
\end{array}$ & $\begin{array}{r}756 \\
\pm 19 \\
\end{array}$ & $\begin{array}{r}390 \\
\pm 60 \\
\end{array}$ \\
\hline
\end{tabular}




\section{ACCEPTED MANUSCRIPT}

\begin{tabular}{|c|c|c|c|c|c|c|c|c|c|c|c|c|c|}
\hline Sample & Level & $\begin{array}{c}U \\
(p p m)\end{array}$ & $\begin{array}{c}\text { Th } \\
\text { (ppm) }\end{array}$ & $\begin{array}{c}\mathrm{K} \\
(\%) \\
\end{array}$ & $\begin{array}{c}\text { ESR } \\
\text { Centre }\end{array}$ & $\begin{array}{c}\text { Bleaching } \\
\text { rate (\%) }\end{array}$ & $\begin{array}{c}D_{e} \\
(G y)\end{array}$ & $\begin{array}{c}D_{\alpha} \\
(\mu G y / a)\end{array}$ & $\begin{array}{c}D_{\beta} \\
(\mu \mathrm{Gy} / \mathrm{a}) \\
\end{array}$ & $\begin{array}{c}\text { in situ } D_{v} \\
(\mu G y / a)\end{array}$ & $\begin{array}{c}D_{\text {cosmic }} \\
(\mu G y / a)\end{array}$ & $\begin{array}{c}D_{a} \\
(\mu G y / a)\end{array}$ & $\begin{array}{l}\text { Age } \\
\text { (ka) }\end{array}$ \\
\hline \multirow[t]{2}{*}{ TVL1302 } & \multirow[t]{2}{*}{1} & \multirow[t]{2}{*}{$\begin{array}{c}0.356 \\
\pm 0.042\end{array}$} & \multirow[t]{2}{*}{$\begin{array}{c}0.830 \\
\pm 0.048\end{array}$} & \multirow[t]{2}{*}{$\begin{array}{c}0.347 \\
\pm 0.006\end{array}$} & $\mathrm{Ti}-\mathrm{Li}$ & 100 & $187 \pm 73$ & $\begin{array}{c}9 \\
\pm 1\end{array}$ & \multirow[t]{2}{*}{$\begin{array}{l}302 \\
\pm 10\end{array}$} & \multirow[t]{2}{*}{$\begin{array}{r}163 \\
\pm 55\end{array}$} & \multirow[t]{2}{*}{$\begin{array}{l}47 \\
\pm 2\end{array}$} & \multirow[t]{2}{*}{$\begin{array}{l}521 \\
\pm 56\end{array}$} & $\begin{array}{r}325 \\
\pm 68\end{array}$ \\
\hline & & & & & $\mathrm{Ti}-\mathrm{H}$ & 100 & $136 \pm 39$ & & & & & & $\begin{array}{r}236 \\
\pm 49 \\
\end{array}$ \\
\hline \multirow{3}{*}{ TVL1304 } & \multirow{3}{*}{ D1 } & \multirow{3}{*}{$\begin{array}{c}0.573 \\
\pm 0.043\end{array}$} & \multirow{3}{*}{$\begin{array}{c}1.377 \\
\pm 0.051\end{array}$} & \multirow{3}{*}{$\begin{array}{c}0.400 \\
\pm 0.006\end{array}$} & $\mathrm{Al}$ & 42 & $687 \pm 255$ & & & & & & $\begin{array}{c}981 \\
\pm 204\end{array}$ \\
\hline & & & & & Ti-Li & 100 & $696 \pm 183$ & $\begin{array}{l}14 \\
\pm 1\end{array}$ & $\begin{array}{c}362 \\
\pm 10\end{array}$ & $\begin{array}{r}260 \\
\pm 54\end{array}$ & $\begin{array}{r}38 \\
\pm 2\end{array}$ & $\begin{array}{r}674 \\
\pm 55\end{array}$ & $\begin{array}{c}994 \\
\pm 206\end{array}$ \\
\hline & & & & & $\mathrm{Ti}-\mathrm{H}$ & 100 & $170 \pm 13$ & & & & & & $\begin{array}{r}243 \\
\pm 14 \\
\end{array}$ \\
\hline
\end{tabular}


ACCEPTED MANUSCRIPT

\begin{tabular}{|c|c|c|c|c|c|c|c|}
\hline \multirow[t]{2}{*}{ Sample } & \multicolumn{3}{|c|}{$\begin{array}{c}\text { CENIEH-RSES } \\
\text { (Faivre et al., 2014) }\end{array}$} & \multicolumn{3}{|c|}{ This study } & \multirow{2}{*}{$\begin{array}{c}\text { Ratio } \\
D_{e}-2 / D_{e}-1\end{array}$} \\
\hline & $D_{e}-1(G y)$ & $D_{\max }(G y)$ & $\operatorname{Dmax} / D_{\mathrm{e}}-1$ & $D_{e}-2(G y)$ & $D_{\max }(G y)$ & $D_{\max } / D_{e}-2$ & \\
\hline T1 & $121 \pm 2$ & 5,000 & 41 & $121 \pm 3$ & 1,000 & 8 & 1.00 \\
\hline $\mathrm{T} 2$ & $175 \pm 2$ & 5,000 & 29 & $178 \pm 4$ & 1,000 & 6 & 1.02 \\
\hline T3 & $142 \pm 4$ & 5,000 & 35 & $134 \pm 4$ & 1,000 & 7 & 0.94 \\
\hline T4 & $165 \pm 2$ & 5,000 & 30 & $160 \pm 2$ & 1,000 & 6 & 0.97 \\
\hline T5 & $155 \pm 4$ & 5,000 & 32 & $150 \pm 7$ & 1,000 & 7 & 0.97 \\
\hline T6 & $153 \pm 4$ & 5,000 & 33 & $149 \pm 7$ & 1,000 & 7 & 0.97 \\
\hline $\mathrm{T} 7$ & $164 \pm 4$ & 5,000 & 30 & $151 \pm 5$ & 1,000 & 7 & 0.92 \\
\hline T8 & $254 \pm 4$ & 5,000 & 20 & $251 \pm 8$ & 1,800 & 7 & 0.99 \\
\hline Mean \pm s.d. & $166 \pm 28(17 \%)$ & & & $153 \pm 22(14 \%)$ & & & 0.97 \\
\hline \multirow[t]{2}{*}{ Sample } & \multicolumn{3}{|c|}{$\begin{array}{c}\text { MNHN } \\
\text { (Bahain et al. ,2015) }\end{array}$} & \multicolumn{3}{|c|}{$\begin{array}{ll}\text { This study } \\
\end{array}$} & Ratio \\
\hline & $D_{e}-1(G y)$ & $D_{\max }(G y)$ & $\operatorname{Dmax} / D_{\mathrm{e}}-1$ & $D_{e}-2(G y)$ & $D_{\max }(G y)$ & $D_{\max } / D_{\mathrm{e}}-2$ & $D_{e}-2 / D_{e}-1$ \\
\hline TVL157 & $221 \pm 3$ & 5,000 & 23 & $217 \pm 7$ & 1,249 & 6 & 0.98 \\
\hline TVL160 & $208 \pm 3$ & 5,000 & 24 & $206 \pm 6$ & 1,249 & 6 & 0.99 \\
\hline TVL219c & $205 \pm 2$ & 5,000 & 24 & $193 \pm 5$ & 1,249 & 6 & 0.94 \\
\hline TVL923 & $205 \pm 1$ & 5,000 & 24 & $201 \pm 3$ & 1,249 & 6 & 0.98 \\
\hline TVL928 & $191 \pm 6$ & 5,000 & 23 & $169 \pm 6$ & 1,249 & 7 & 0.88 \\
\hline TVL929 & $191 \pm 6$ & 5,000 & 26 & $183 \pm 4$ & 1,249 & 7 & 0.96 \\
\hline Mean \pm s.d. & $207 \pm 6(3 \%)$ & & & $195 \pm 14(7 \%)$ & & & 0.96 \\
\hline
\end{tabular}




\section{ACCEPTED MANUSCRIPT}

Analytical steps
Preparation
Selected grain size
Impact of preparation on alpha and
beta dose rate
Number of dose irradiation steps
Maximum irradiation dose $\left(D_{\max }\right)$
Measurement of the ESR intensity
Fitting function - data weighting
Fitting program
U-series analyses of dental tissues

Alpha efficiency

$R n$ loss in dental tissues

Water content of dental tissues

Radioelement contents in sediment

Water content of sediment

Dose rate conversion factors

In situ gamma measurements

Cosmic dose rate

Age calculation program
CENIEH-RSES

Mechanic with dentist drill

100-200 $\mu \mathrm{m}$

Data from Marsh (1999)

Data from Brennan et al. (1997)

10

5,000 Gy

Peak-to-peak amplitude (T1B2; Grun, 2000b)

Single Saturating Exponential (SSE) - Inverse of the squared ESR intensities $\left(1 / I^{2}\right)$ Origin

High resolution Laser Ablation ICP-MS analyses (as in Solution alpha spectrometry bulk analyses Grün et al., 2014)

The U-series data from all the laser ablation spots of a given tissue were combined to provide the data input for the ESR age calculations

$0.13 \pm 0.02$ (Grün and Katzenberger-Apel, 1994)

Equilibrium was assumed

Determined by cross-checking data from High resolution gamma spectrometry (HRGS) and

Enamel $=0 \% \mathrm{wgt}$

Dentine $=5 \pm 3 \% \mathrm{wgt}$

Determined by ICP-MS/OES

The values were used to derive the beta and gamma dose rates

$20 \pm 10 \%$ wgt

Guérin et al. (2011)

No (gamma dose rate calculated from radioelement contents)

Calculated from present-day depth (according with the tables of Prescott and Hutton, 1988, 1994)

DATA program (US-ESR and CS-USESR ages) (Grün, 2009) alpha spectrometry analyses

$$
\text { Enamel }=0 \% \text { wgt }
$$

Dentine $=7 \pm 5 \% \mathrm{wgt}$

Determined by HRGS

The values were used to derive the beta rose rates

$15 \pm 5 \%$ wgt

Adamiec and Aitken (1998)

Yes (Nal probe connected to a Inspector1000

Canberra multichannel analyzer) on a section close to the excavation area.

Gamma dose rates were obtained with the Threshold method (Mercier and Falguères, 2007). A mean gamma dose rate was derived within layer D2. based on Jamet's geological interpretation (according with the tables of Prescott and Hutton, 1988, 1994)

USESR (US, Shao et al., 2014) and DATA (CS-US, Grün, 2009) programs from the 4 in situ measurements performed

Calculated using a three stage model evolution 


\section{ACCEPTED MANUSCRIPT}

\begin{tabular}{|c|c|c|}
\hline Analytical protocol & MNHN & BRGM \\
\hline Preparation & \multicolumn{2}{|c|}{ Quartz extraction and purification procedure following Voinchet et al. (2004) } \\
\hline Selected grain size & \multicolumn{2}{|c|}{$100-200 \mu \mathrm{m}$} \\
\hline Number of irradiation steps & \multicolumn{2}{|c|}{10} \\
\hline$D$ max & $9,870 \mathrm{~Gy}$ & $11,700 \mathrm{~Gy}$ \\
\hline ESR signal & Al (Toyoda and Falguères, 2003) & $\begin{array}{l}\text { Al (Toyoda and Falguères, 2003), } \\
\text { Ti-Li and Ti-H (Toyoda et al., 2000; } \\
\text { Tissoux et al., 2008) }\end{array}$ \\
\hline ESR intensity & Al -From the top of the peak at $\mathrm{g}=2.018 \mathrm{ar}$ & $\begin{array}{l}\text { the bottom of the } 16 \text { th peak at } g=2.002 \\
\text { Ti-Li - from the bottom of the peak at } g= \\
1.913 \text { to the baseline } \\
\text { Ti-H - from the bottom of the doublet at } \mathrm{g} \\
=1.915 \text { to the baseline }\end{array}$ \\
\hline Fitting function (data weighting) & \multicolumn{2}{|c|}{$\mathrm{E}+\mathrm{L}(1 / \mathrm{I} \underline{2}) \quad=1.915$ to the baseline } \\
\hline Fitting program & \multicolumn{2}{|c|}{ Origin } \\
\hline Alpha efficiency & \multicolumn{2}{|c|}{$0.15 \pm 0.10$ (Laurent et al., 1998) } \\
\hline Sediment radioelement contents & \multicolumn{2}{|c|}{ Determined by HRGS } \\
\hline Post $R n$ disequilibrium in the $U-238$ series & \multicolumn{2}{|c|}{ No disequilibrium observed } \\
\hline Water content of sediment & Measured values (5-8 \% wgt) & $\begin{array}{c}15 \pm 5 \% \text { wgt (measured values : } 10-12 \% \\
\text { wgt) }\end{array}$ \\
\hline In situ gamma measurements & $\begin{array}{l}\text { Yes (Nal probe, Inspector } 1000, \text { Canberra), } \\
\text { directly at the sampling spot }\end{array}$ & $\begin{array}{l}\text { Yes (Nal probe, Digidart LF gamma, } \\
\text { Ortec), directly at the sampling spot }\end{array}$ \\
\hline Cosmic dose rate & \multicolumn{2}{|c|}{$\begin{array}{l}\text { Calculated from present-day depth (according to the tables of Prescott and Hutton, } \\
\qquad 1988,1994)\end{array}$} \\
\hline $\begin{array}{c}\text { Grain size attenuation for alpha and beta } \\
\text { dose rate }\end{array}$ & \multicolumn{2}{|c|}{ Brennan (2003) and Brennan et al._(1991) } \\
\hline Dose rate factor conversions & \multicolumn{2}{|c|}{ Adamiec and Aitken (1998) } \\
\hline Age calculation program & \multicolumn{2}{|c|}{ ESR MNHN program } \\
\hline
\end{tabular}




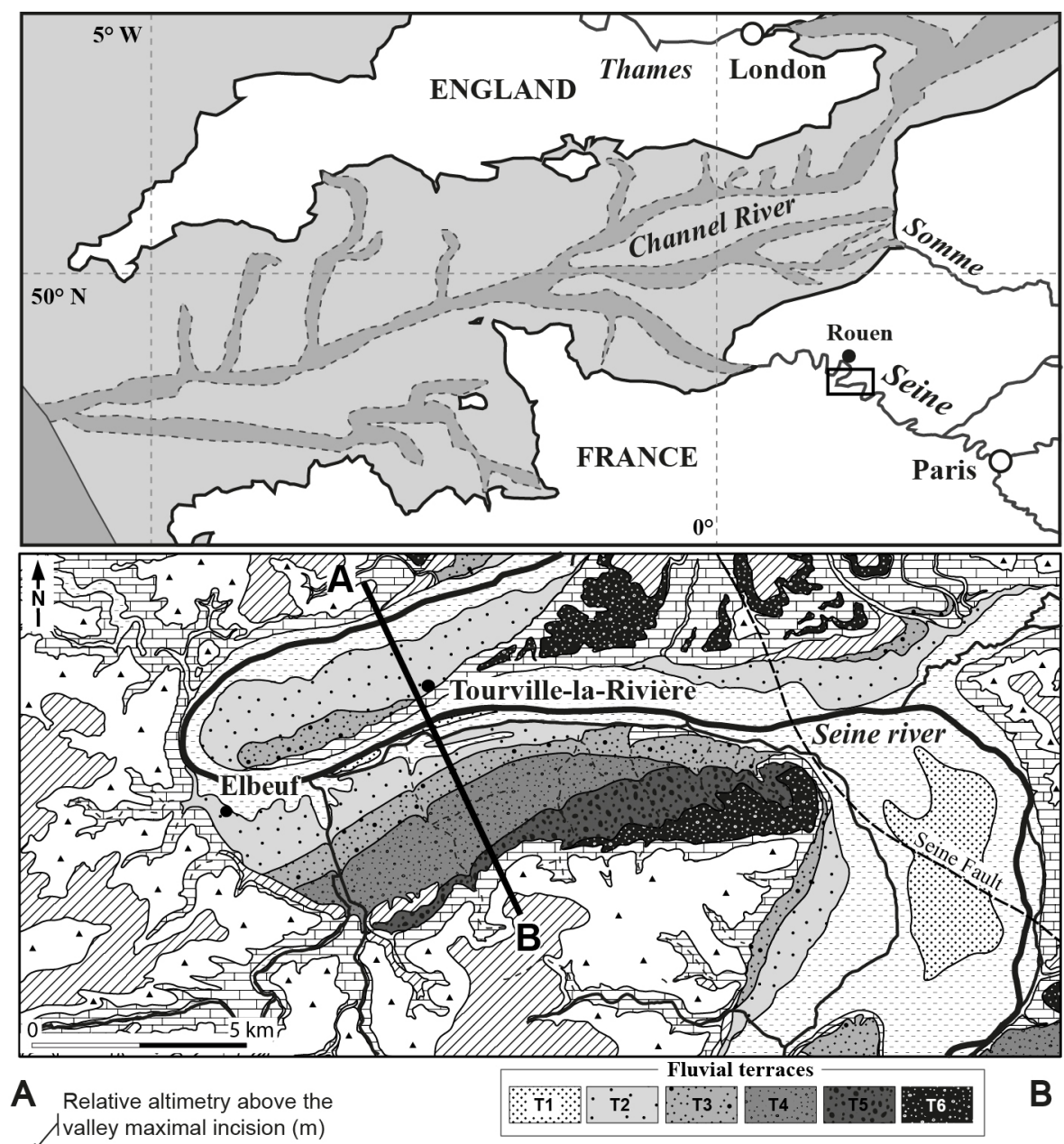

valley maximal incision (m)

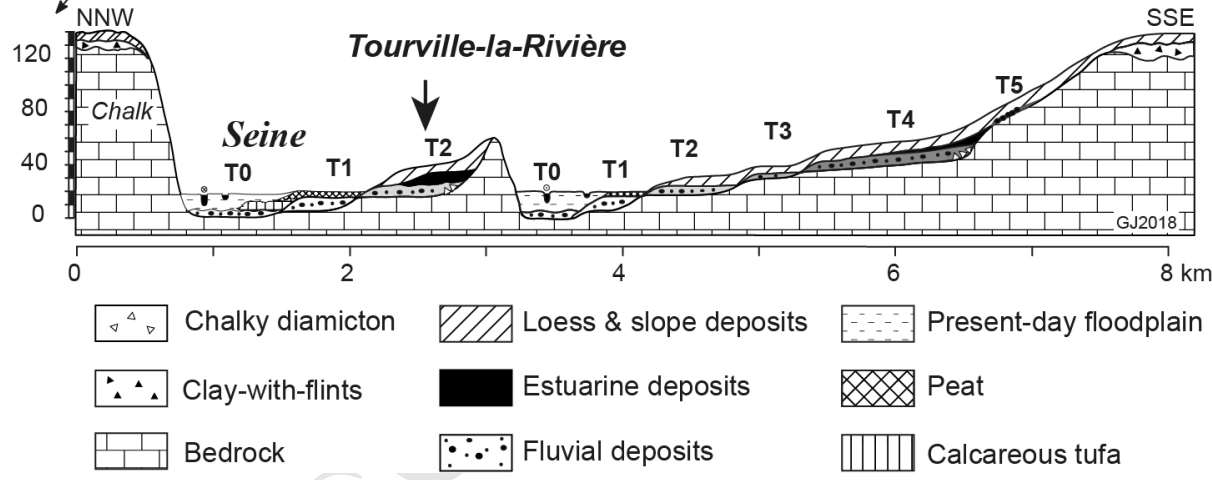


Stratigraphical Lithostratigraphical description Biomarkers palaeoclimatic inference Chronological data (Stremme, 1985; units (Lautridou, 1985 ; Jamet, 2014) - (Lautridou, 1985 ; Jamet, 2015) Occhietti et al, 1987; Balescu et al, 1997)

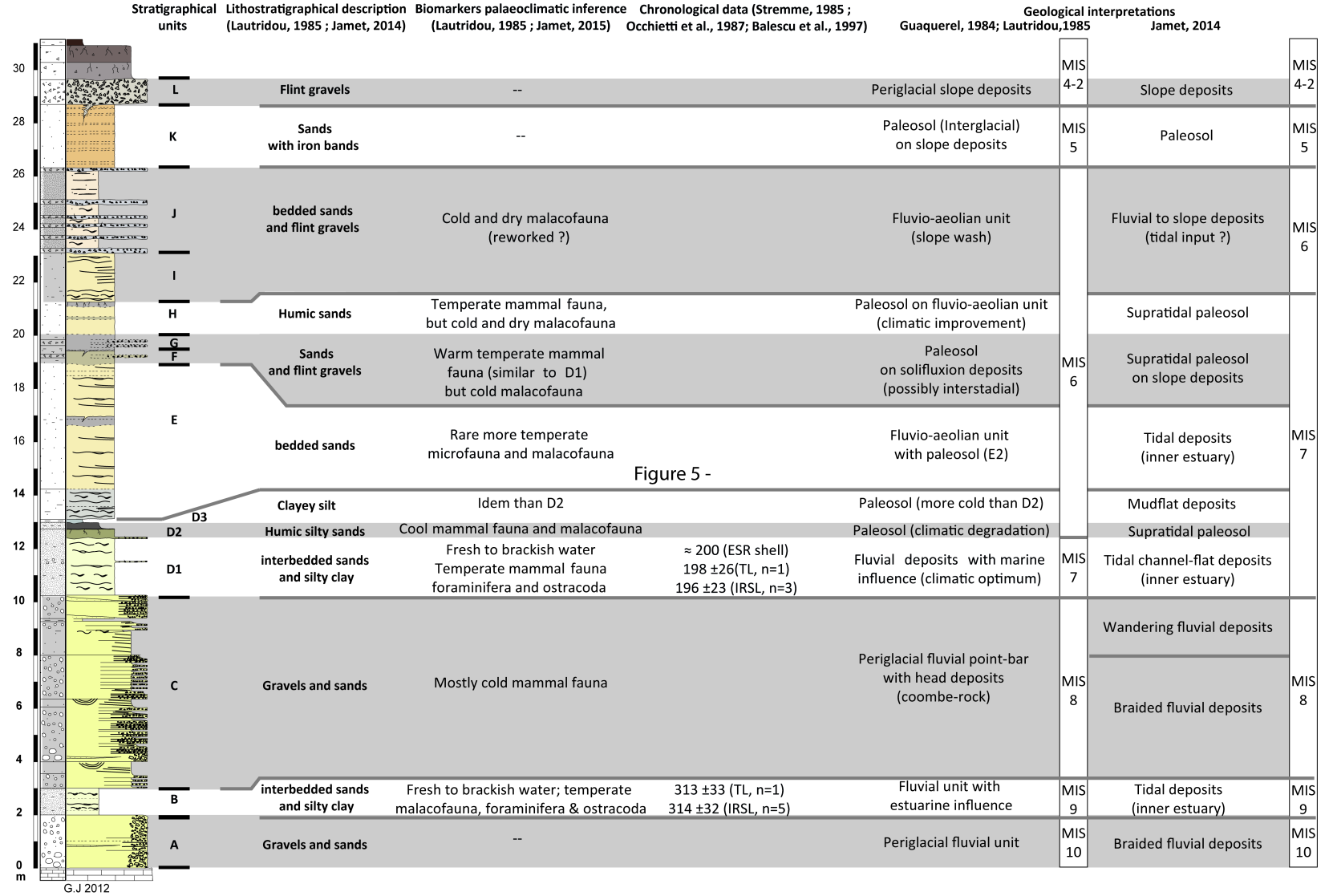

Figure 2 - Tourville 


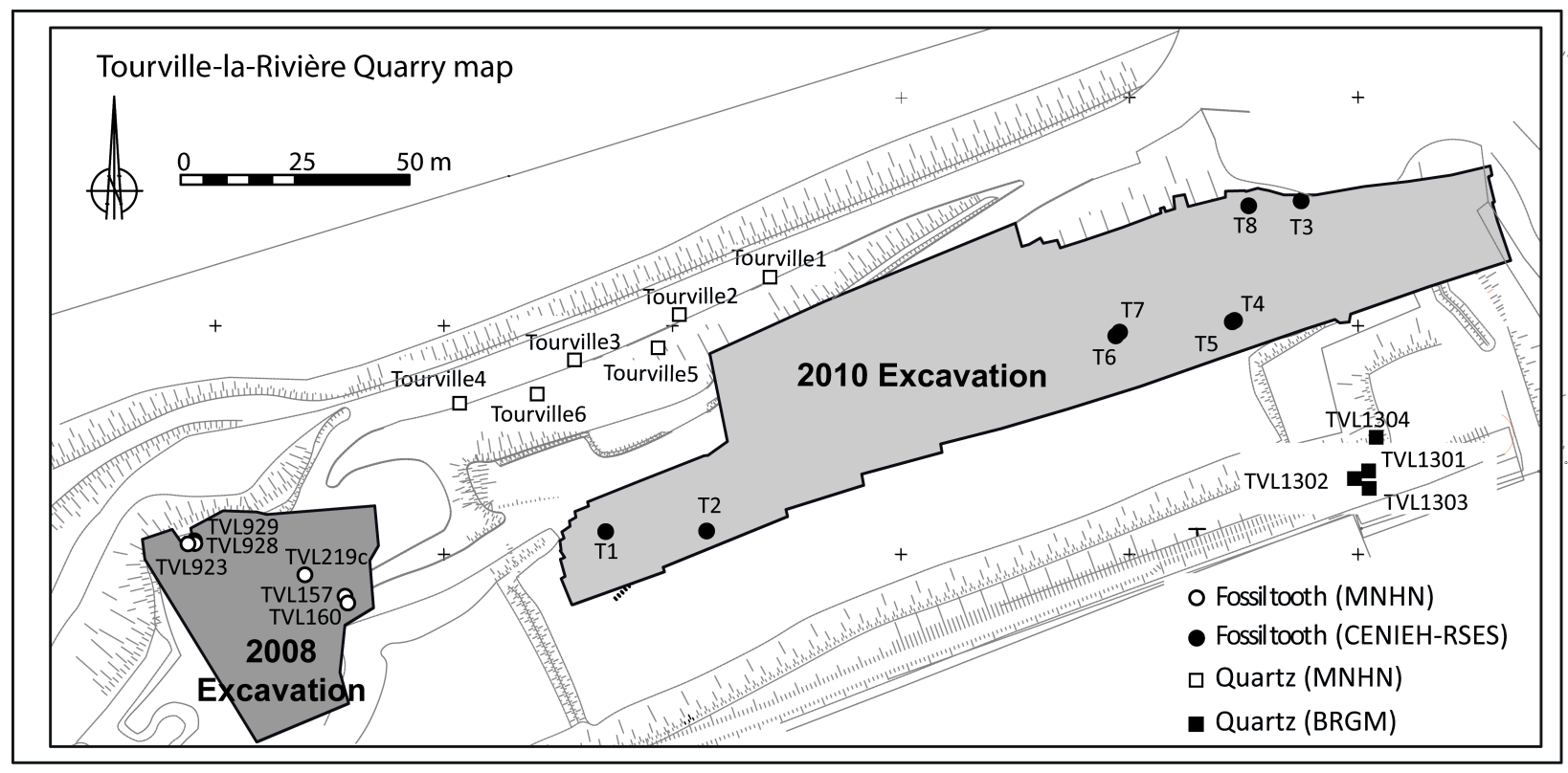

Figure 3 - Tourville 


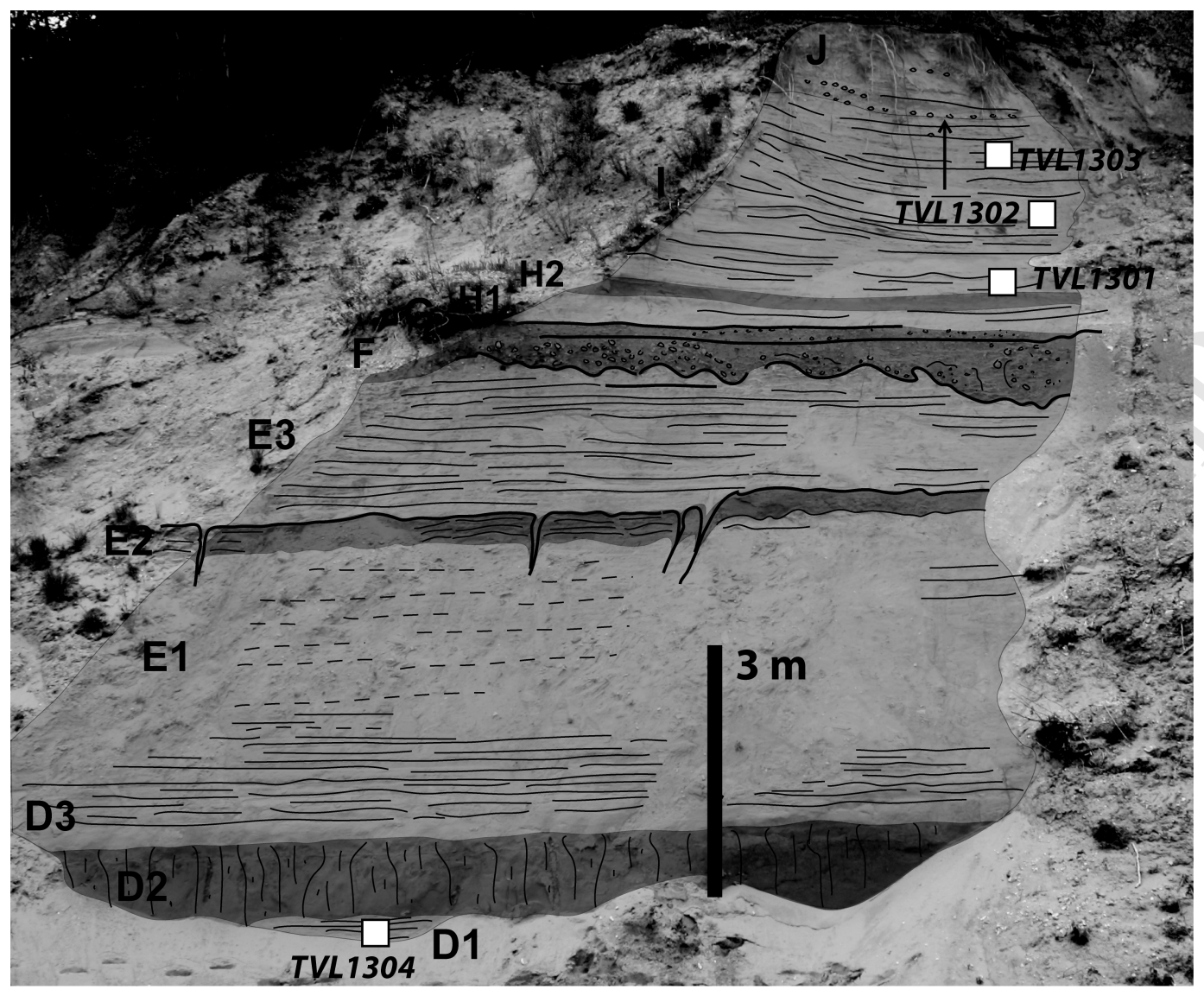

Figure 4 - Tourville 
Figure 5 - Tourville

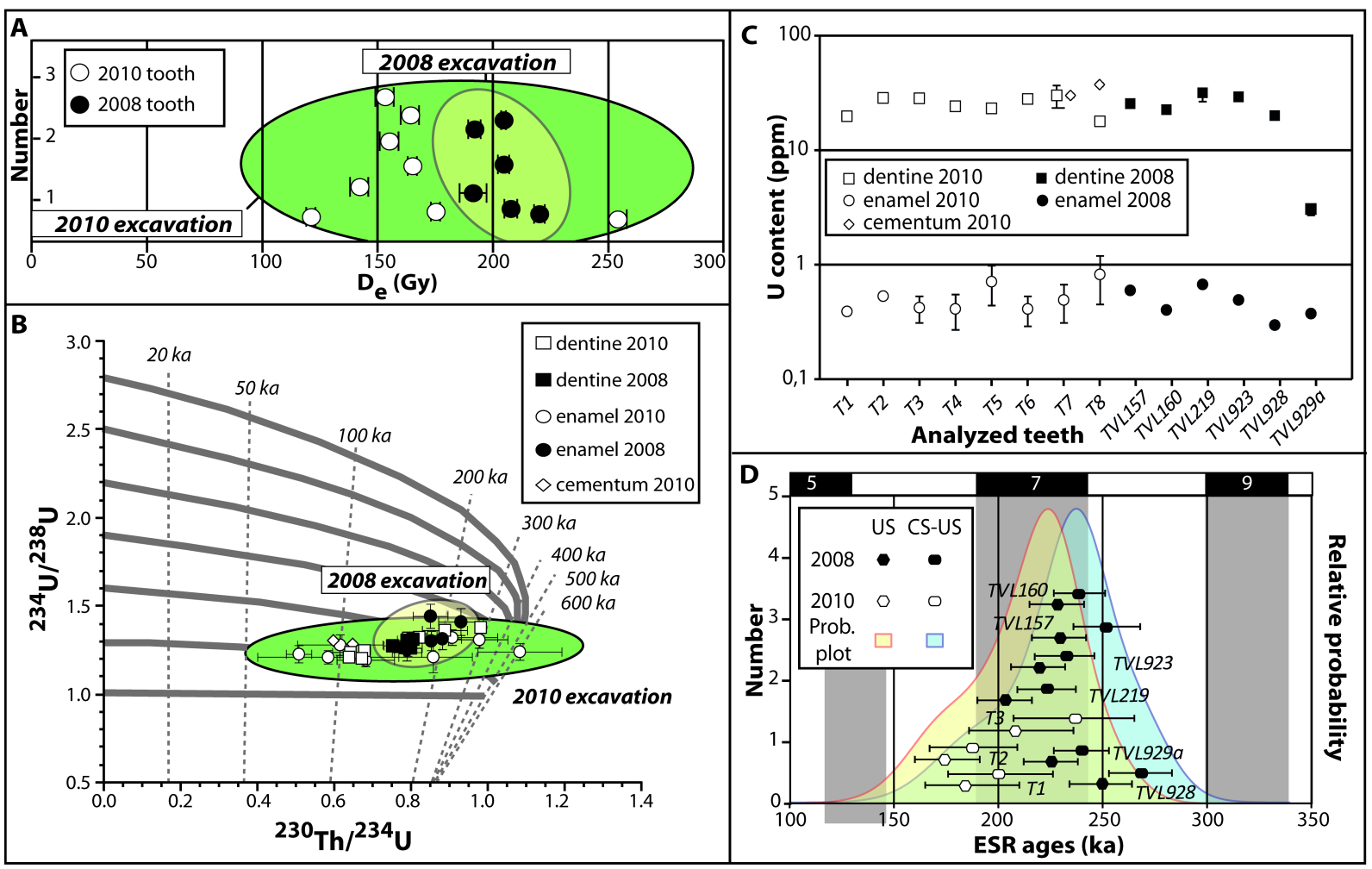




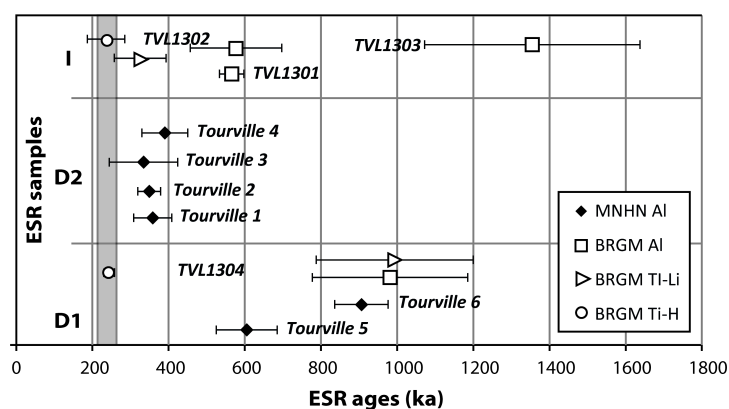

Figure 6 - Tourville 


\section{Accepted Manuscript}

ESR and ESR/U-series chronology of the Middle Pleistocene site of tourville-la-rivière (normandy, France) - A multi-laboratory approach

B.A.H.A.I.N. Jean-Jacques, Mathieu Duval, Pierre Voinchet, Hélène Tissoux,

Christophe Falgueres, Rainer Grün, Davinia Moreno, Qingfeng Shao, Olivier Tombret,

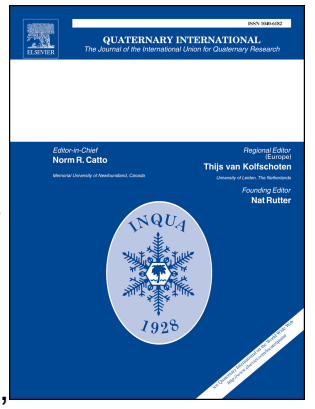

Guillaume Jamet, F.A.I.V.R.E. Jean-Philippe, Dominique Cliquet

PII:

$$
\text { S1040-6182(18)30879-6 }
$$

DOI:

$$
\text { https://doi.org/10.1016/j.quaint.2019.06.015 }
$$

Reference: JQI 7903

To appear in: Quaternary International

Received Date: 30 July 2018

Revised Date: 15 March 2019

Accepted Date: 11 June 2019

Please cite this article as: Jean-Jacques, B.A.H.A.I.N., Duval, M., Voinchet, P., Tissoux, Héè., Falgueres, C., Grün, R., Moreno, D., Shao, Q., Tombret, O., Jamet, G., Jean-Philippe, F.A.I.V.R.E., Cliquet, D., ESR and ESR/U-series chronology of the Middle Pleistocene site of tourville-la-rivière (normandy, France) - A multi-laboratory approach, Quaternary International (2019), doi: https:// doi.org/10.1016/j.quaint.2019.06.015.

This is a PDF file of an unedited manuscript that has been accepted for publication. As a service to our customers we are providing this early version of the manuscript. The manuscript will undergo copyediting, typesetting, and review of the resulting proof before it is published in its final form. Please note that during the production process errors may be discovered which could affect the content, and all legal disclaimers that apply to the journal pertain. 